Review

\title{
Exercise-Induced Myokines can Explain the Importance of Physical Activity in the Elderly: An Overview
}

\author{
Jenny Hyosun Kwon ${ }^{1}$, Kyoung Min Moon ${ }^{2, *}$ and Kyueng-Whan Min ${ }^{3}$ \\ 1 Department of Kinesiology, Indiana University, Bloomington, IN 47405, USA; jenkwon@iu.edu \\ 2 Department of Pulmonary, Allergy, and Critical Care Medicine, GangNeung Asan Hospital, \\ University of Ulsan College of Medicine, Gangneung 25440, Korea \\ 3 Department of Pathology, Hanyang University Guri Hospital, Hanyang University College of Medicine, \\ Guri 11923, Korea; kyueng@gmail.com \\ * Correspondence: pulmogicu@ulsan.ac.kr
}

Received: 9 September 2020; Accepted: 27 September 2020; Published: 1 October 2020

\begin{abstract}
Physical activity has been found to aid the maintenance of health in the elderly. Exercise-induced skeletal muscle contractions lead to the production and secretion of many small proteins and proteoglycan peptides called myokines. Thus, studies on myokines are necessary for ensuring the maintenance of skeletal muscle health in the elderly. This review summarizes 13 myokines regulated by physical activity that are affected by aging and aims to understand their potential roles in metabolic diseases. We categorized myokines into two groups based on regulation by aerobic and anaerobic exercise. With aging, the secretion of apelin, $\beta$-aminoisobutyric acid (BAIBA), bone morphogenetic protein 7 (BMP-7), decorin, insulin-like growth factor 1 (IGF-1), interleukin-15 (IL-15), irisin, stromal cell-derived factor 1 (SDF-1), sestrin, secreted protein acidic rich in cysteine (SPARC), and vascular endothelial growth factor A (VEGF-A) decreased, while that of IL-6 and myostatin increased. Aerobic exercise upregulates apelin, BAIBA, IL-15, IL-6, irisin, SDF-1, sestrin, SPARC, and VEGF-A expression, while anaerobic exercise upregulates BMP-7, decorin, IGF-1, IL-15, IL-6, irisin, and VEGF-A expression. Myostatin is downregulated by both aerobic and anaerobic exercise. This review provides a rationale for developing exercise programs or interventions that maintain a balance between aerobic and anaerobic exercise in the elderly.
\end{abstract}

Keywords: myokine; elderly; exercise; physical activity; aerobic; anaerobic

\section{Introduction}

Owing to the improvements in healthcare and nutrition, life expectancy is increasing rapidly across the globe. It has been estimated that the elderly population, i.e., people over 60 , will have increased by over $200 \%$ between 1970 and 2025 [1]. With the continued increase in life expectancy, health problems that afflict the elderly have garnered much attention. The prevalence of chronic diseases, such as diabetes, cancers, and cardiovascular, respiratory, and arthritic diseases, is increasing as the aging of the global population accelerates [2,3]. Skeletal muscle loss is among the most serious physical changes that the elderly experience. Approximately $75 \%$ of the individuals over 65 years of age do not indulge in the minimum physical activity required to stay healthy [4]. Skeletal muscle loss is a major health hazard as it is causally related to sarcopenia [5]. This muscular atrophy is associated with the development of sarcopenia, which is defined as a progressive decline in skeletal muscle mass and strength without loss of overall body weight that occurs with aging [6]. Individuals who spend much time sitting are prone to muscle mass loss and weakness, and therefore, they are at higher risk of developing sarcopenia [7]. In 1931, Critchley first recognized that the intrinsic mass 
of the hand and foot muscles decreased with aging [8]. Muscle weakness and decreased muscle mass negatively affect the elderly, both physiologically and psycho-socially, as they cause difficulty in performing daily tasks, increasing the risk of falling, reducing independence and quality of life, and increasing depression, social isolation, physical inactivity (sedentarism), susceptibility to chronic diseases, and rates of all-cause mortality [9-11]. The World Health Organization (WHO) announced that physical inactivity ( $5.5 \%$ of the total or 3.2 million) is the fourth most serious global health risk associated with mortality following high blood pressure, tobacco use, and high blood glucose [12].

Skeletal muscles are attached to bones by tendons and aponeuroses and are under the voluntary control of the somatic nervous system. They account for $30-50 \%$ of the total body mass and are primarily responsible for locomotion and metabolic homeostasis [13]. In recent decades, it has been discovered that contracting skeletal muscles release various hormone-like substances $[14,15]$. These activators are called myokines, which are small proteins (5-20 kDa) and proteoglycan peptides that are produced and secreted by skeletal muscle cells in response to muscle contractions $[16,17]$. Early in the study of myokines, it was hypothesized that high levels of exercise-induced circulating cytokine IL- 6 released by immune cells (NK cells and CD8+ cells) were associated with muscle damage [18]. Although the plasma IL-6 concentration increases approximately 100-fold after exercise, it normalizes rapidly [19]. Electric stimulation inducing the rat gastrocnemius and soleus muscles produced contraction without injury and resulted in increased IL-6 [20]. Furthermore, in humans, the IL-6 turnover in the femoral arteries and veins has been demonstrated to be very sensitive to muscle exercise [21]. These results suggest that skeletal muscle contraction is associated with IL-6 secretion. However, it remains possible that free macrophages in the blood enter the skeletal muscle and secrete IL-6 during muscle contractions. Recently, with the development of molecular analysis techniques, such as quantitative real-time PCR and a new contractile C2C12 myotube model, it has been directly demonstrated that IL-6 is secreted by skeletal muscles [22-25]. Various myokines secreted by skeletal muscles during aerobic and anaerobic exercises have been studied in connection with various human diseases using state-of-the-art techniques, including total RNA sequencing [26-28]. For a long time, skeletal muscles were only recognized as being involved in the physical aspects of exercise. However, with the discovery of exercise-induced myokines, skeletal muscles have been demonstrated to be involved in the maintenance of metabolic homeostasis. Although the detailed mechanisms are not clear, both skeletal muscle contraction and mass maintenance appear to be actively involved in maintaining health and preventing disease development in the elderly, particularly considering the rapid deterioration of muscle physiology with aging.

Thus, studies on myokines are necessary for ensuring the maintenance of skeletal muscle health in the elderly. This review summarizes the myokines regulated by physical activity that are affected by aging and aims to understand their potential roles in metabolic diseases. We have reviewed 13 myokines whose secretion is influenced by aging but controlled by physical activity. We categorized these myokines into two groups, one regulated by aerobic exercise and the other by anaerobic exercise. With aging, the secretion of apelin, BAIBA, BMP-7, decorin, IGF-1, IL-15, irisin, SDF-1, sestrin, SPARC, and VEGF-A decreased, while that of IL- 6 and myostatin increased. Aerobic exercise upregulates apelin, BAIBA, IL-15, IL-6, irisin, SDF-1, sestrin, SPARC, and VEGF-A expression, while anaerobic exercise upregulates BMP-7, decorin, IGF-1, IL-15, IL-6, irisin, and VEGF-A expression. Myostatin is downregulated by both aerobic and anaerobic exercise.

\section{Myokines}

\subsection{Apelin}

Human apelin was identified and isolated in 1998 as an endogenous ligand of the G-protein-coupled receptor APJ and was named the APJ endogenous ligand. The apelin gene located at chromosome Xq25-26.1, encodes a 77 amino acid preproprotein [29,30]. After the cleavage of the signal peptide, the protein is processed into various bioactive endogenous peptides, such as apelin-13, $-16,-17$, 
and -36 [31], which are widely expressed in various organs. Apelin regulates a wide range of physiological processes, including blood pressure [32], cardiac contractility [33], and angiogenesis [34], and is involved in pathophysiological processes underlying hypoxia [35], obesity [36], diabetes [37], and various cancers [38].

In one study, myokine expression in the vastus lateralis was examined in 11 obese nondiabetic males after cycling and running (aerobic exercise) for 8 weeks; in contrast to what is known for the other known myokines, this study reported a significant increase in the expression and secretion of apelin. This was the first study to recognize apelin as a myokine [39]. A reduction in apelin has also been observed in elderly subjects. In particular, abnormalities in muscle function grow more severe with age in apelin (-/-) mice. Thus, apelin has been suggested as a biomarker for diagnosing early sarcopenia and a target for the development of therapeutic agents for age-associated muscle weakness [40]. Also, Rai et al. showed that the downregulation of the apelinergic axis accelerated the onset and progression of aging [41].

The concentration of plasma apelin increases in response to aerobic exercise. Apelin mRNA expression increased by approximately $40 \%$ in hypertensive rats in response to swimming training for 9 weeks, and had positive effects on hypertension [42]. Apelin mRNA expression in the vastus lateralis was upregulated 3.3-fold after 11 obese males were subjected to aerobic exercise (cycling and running) for 8 weeks [39]. Skeletal muscle from mice subjected to aerobic exercise (treadmill and ladder) and $\mathrm{C} 2 \mathrm{C} 12$ cells treated with the exercise mimetic, forskolin showed increased apelin plasma and mRNA concentrations, respectively [43]. Furthermore, a combination of apelin treatment and exercise (treadmill) significantly reduces ischemia-reperfusion injury in rats [44].

\section{2. $\beta$-aminoisobutyric Acid (BAIBA)}

BAIBA $\left(\mathrm{C}_{4} \mathrm{H}_{9} \mathrm{NO}_{2}\right)$ is a small, non-protein myokine with a molecular weight of $103.6 \mathrm{Da}$ that was first discovered in human urine in 1951 [45]. It is secreted by contracting muscles via the action of peroxisome proliferator-activated receptor- $\gamma$ coactivator $1 \alpha$ (PGC- $1 \alpha)$ and acts in a myokine-specific manner [46,47]. It is involved in various metabolic processes, such as acting on white adipose tissue to upregulate brown adipose tissue-specific genes, enhancing PGC- $1 \alpha$ expression to increase lipid oxidation, suppressing inflammation in skeletal muscles, inhibiting cardiometabolic risk factors, and suppressing endoplasmic reticulum stress in hepatoblastoma cells. Blood BAIBA levels increase in response to continuous exercise [46,48-50]. The myokine properties of BAIBA suggest that many small molecule metabolites may have myokine functions.

Although its various functions are known, few studies have investigated the function of BAIBA in aging skeletal muscles. Plasma BAIBA levels are higher in young subjects than those in the elderly [51]. This could be because BAIBA expression is regulated by PGC- $1 \alpha$, and PGC- $1 \alpha$ expression is lower in elderly subjects than that in young subjects $[52,53]$. This difference in PGC- $1 \alpha$ expression is considered to be aging-dependent during acute exercise. BAIBA secretion is unchanged in young and old muscle; however, the expression of its receptor (Mas-related G-protein receptor Type D) decreases markedly in an age-dependent manner in osteocytes [54-56].

Secretion of BAIBA by skeletal muscles increases in mice overexpressing PGC- $1 \alpha$. Additionally, high plasma BAIBA concentrations are observed in humans undergoing wheel-running exercise but are inversely correlated with metabolic risk factors, which suggests that BAIBA may protect against metabolic diseases [46,57-59]. In one study, blood BAIBA levels were measured after 16 weeks of aerobic exercise training in Native American boys and girls (11-17 years) divided into obese and normal-weight groups. Individuals in the normal-weight group had 29\% higher BAIBA levels than those in the obese group [60]. Physical inactivity in patients on hemodialysis reduces plasma BAIBA concentrations [61,62]. Kitase et al. reported that BAIBA functions as an osteocyte survival factor, protects against mitochondrial degradation due to ROS (reactive oxygen species), and regulates bone and skeletal muscle loss due to aging [54]. These results indicate that BAIBA is an important regulator of metabolic activity and is affected by a lack of exercise, which is frequently seen in the elderly. 


\subsection{Bone Morphogenetic Protein 7 (BMP-7)}

In 1965, Urist recognized BMP as an important factor in osteogenesis and bone formation [63]. BMP-7, also called osteogenic protein- 1 , is a member of the TGF- $\beta$ superfamily of cysteine-knot fold cytokine-growth factors [64]. Human BMP-7 has been isolated and mapped to chromosome 20q13.31. This has been proposed as a possible locus for the Holt-Oram syndrome, which manifests as skeletal abnormalities of the upper limbs and hands [65-67]. BMP-7 is a multifunctional growth factor involved in cell proliferation, apoptosis, organ repair, and differentiation of brown adipose tissue, but its most important function is inducing cartilage and bone formation [68-71].

BMP-7 mRNA and protein levels are lower in elderly subjects, in both humans and rats, compared to young ones [72,73]. BMP-7 mRNA and protein are also expressed at low levels in articular cartilage of elderly subjects with osteoarthritis [74] owing to methylation of the BMP-7 promoter [75].

BMP-7 induces myotube formation in the mouse pluripotent mesenchymal precursor cell line $\mathrm{C} 2 \mathrm{C} 12$ and causes increased expression of muscle differentiation factors such as BMP-1, GDF-6, and GDF-8 [76]. Winbanks et al. demonstrated that BMP-7 is a positive regulator of skeletal muscle mass in a neurogenic atrophy model [77]. Biomechanical stimulation $(1 \mathrm{~Hz}$ for $3 \mathrm{~h} /$ day $)$ increased BMP-7 mRNA expression in rat osteoblasts and inhibited posttraumatic osteoarthritis [78]. Expression of BMP-7 mRNA and protein increased in the gastrocnemius and lower limbs skeletal muscles of rats (rectus femoris, vastus lateralis, and gastrocnemius) after endurance training and gradual exercise, respectively $[73,79]$.

\subsection{Decorin}

Human decorin is a small leucine-rich proteoglycan of $90-140 \mathrm{kDa}$ that is associated with collagen fibrils in all connective tissue. The gene is located on chromosome 12q23 [80] and regulates transforming growth factor (TGF)-beta 1 activity as well as the cell cycle [81]. Decorin suppresses myostatin activity, which is associated with obesity and diabetes [47]. In 2014, decorin was first recognized as a myokine, and its levels in both plasma and skeletal muscle increase in response to physical activity [82].

A study that compared young (0-15 years) and old (16-83 years) individuals demonstrated that decorin mRNA expression decreases significantly in an age-dependent manner in human skin fibroblast [83]. In one study, the molecular weight of decorin isolated from the placenta of an old rat was estimated to be approximately $40 \mathrm{kDa}$, which is smaller than that of the normal protein (approximately $100 \mathrm{kDa}$ ). The smaller size was attributed to variations in the glycosaminoglycan base structure with aging [84]. Age-dependent changes in decorin have also been observed in human skin [85]. Although tendon injuries occur very frequently in the elderly, few studies have investigated the relationship between decorin and aging tendons. Dunkman et al. reported that decorin expression is closely related to the changes in aging tendons $[86,87]$.

Articular cartilage decorin levels increase in beagle dogs after long-distance running exercise (40 km/day, 15 weeks) [88]. In 31 young men, decorin mRNA in the vastus lateralis, but not that in the patellar tendon, increased after exercise on a Krogh ergometer [89]. Anaerobic exercise upregulates decorin levels in the human plasma and decorin mRNA in the vastus lateralis, and regulates the expression of genes coding for proteins, such as follistatin, Myod1, atrogin1, and MuRF1, which are involved in hypertrophic pathways in the skeletal muscle [82]. When rats were subjected to moderate exercise on a treadmill, the expression of decorin at mRNA and protein levels increased, whereas they decreased in the calcaneal tendon during strenuous treadmill running. Increased decorin levels regulate matrix metalloproteinase-2 and tissue inhibitor of metalloproteinase-2 expression in the surrounding tissue, which makes the tendon stronger [90].

\subsection{Insulin-Like Growth Factor 1 (IGF-1)}

In 1957, IGF-1 was first recognized by Salmon and Daughaday as a "sulfation factor" that stimulates sulfate incorporation in rat cartilage [91]. In 1978, Rinderknecht and Humbel purified 
a human IGF-1, a protein of 70 amino acids with structural resemblance to proinsulin [92]. In 1983, the human IGF-1 cDNA was cloned, and in 1984, IGF-1 was found to be located on chromosome 12q23.2 [93,94]. Although IGF-1 is a multifunctional peptide, its main physiological function is as a growth hormone (GH) essential for normal bone and tissue growth and development [95]. In 2012, IGF-1 was recognized as a myokine produced and secreted by the muscle fibers [96].

Plasma IGF-1 decreases with age in humans, leading to GH release impairment, immunocompetence, and GH-IGF axis activity [97-101]. Furthermore, DNA synthesis and proliferation are observed in response to aging-associated low IGF-1 levels [102,103]. IGF-1 gene-ablated (IGF-1-/-) mice are characterized by severely impaired health [104] and poor mitochondrial function in the hippocampus [105]. IGF-1 levels have been reported to be low in community-dwelling elderly subjects and shows promise as a biomarker for sarcopenia [106,107].

Several studies have shown that impaired IGF-1 activity results in muscular dysfunction. Elderly marathon runners have high GH-IGF activity, which indicates that exercise in the elderly is closely related to IGF-1 activity [108]. IGF-1 is upregulated in response to anaerobic exercise, such as weightlifting in 72- to 98-year-old women [109]. Additionally, rats with spinal cord injury exhibited IGF-1 upregulation in the soleus after treadmill training, which resulted in the upregulation of muscle regeneration markers, such as myogenin and MyoD [110]. Significantly increased IGF-1 mRNA expression has been reported in postmenopausal women after a single-leg extension exercise [111].

\subsection{Interleukin-15 (IL-15)}

Human IL-15 was reported simultaneously by two groups in 1994 as a T-cell growth factor. IL-15, located on chromosome 4q31, encodes a 14-15 kDa glycoprotein incorporating a four $\alpha$-helix bundle [112-114]. In humans, IL-15 expression is detected in various cells and tissues, including skeletal muscle, epithelial cells, monocytes, and dendritic cells [115]. The primary biological functions of IL-15 are to activate and proliferate T-cells and NK cells, inhibit apoptosis, and accelerate CD8(+) antitumor immunity [116-118]. Brandt and Pedersen suggested in 2010 that muscle-derived IL-15 is a myokine constitutively expressed by skeletal muscles and is regulated in response to strength training [119].

The levels of plasma IL-15, quadriceps IL-15, and gastrocnemius IL-15 decline gradually with age in rodents $[120,121]$. Plasma IL-15 levels also decrease with age in humans [122]. Elderly subjects with sarcopenia have significantly lower plasma IL-15 levels, and studies have reported a relationship between sarcopenia and insufficient plasma IL-15 levels [123,124]. Age-dependent upregulation of IL-15 has been reported in splenic stromal cells but not in skeletal muscle [125].

Several studies have shown that exercise upregulates plasma IL-15 levels as well as IL-15 mRNA and protein levels in skeletal muscle. In one study, a noticeable increase in plasma IL-15 levels was observed in 76 men and 77 women after 10 weeks of weight training (i.e., chest press, seated row, hamstring curl, incline press) [126]. Pérez-López et al. reported a significant increase in plasma IL-15 levels and muscle IL-15 mRNA and protein levels after leg press and knee extension resistance exercises [127]. In rats with type 2 diabetes, the expression of IL-15 protein increased significantly in the soleus after 12 weeks of aerobic exercise (treadmill training) [128] and increased by $40 \%$ in the vastus lateralis of 30 men after 12 weeks of endurance exercise on a cycloergometer [129]. Upregulation of IL-15 after treadmill running increases fibroblast collagen synthesis and cell proliferation via the AMPK-Activated Protein Kinase, signaling pathway [122]. Hingorjo et al. demonstrated a twofold increase in plasma IL-15 levels after a single session of submaximal aerobic exercise [130]. Plasma IL-15 levels more than doubled in 37 athletes (11 females and 26 males) who performed acute long-distance ( $35 \mathrm{~km})$ endurance exercise [131].

\subsection{Interleukin-6 (IL-6)}

IL-6 is a cytokine that plays multifunctional roles in the regulation of the immune system, nervous system, and glucose homeostasis [132,133]. IL-6 has several names, including interferon beta-2 
(IFNB2), B-cell stimulatory factor 2 (BSF2), hepatocyte stimulatory factor, and hybridoma growth factor. Zilberstein et al. and Hirano et al. cloned full-length cDNAs encoding human IFNB2-a $23.7 \mathrm{kDa}$ protein comprising 212 amino acids-and human BSF2-a novel interleukin comprising 184 amino acids—respectively $[134,135]$. Using in situ hybridization, Sutherland et al. identified that IFNB2 is located on chromosome 7p15.3 [136]. The extramembrane (IL-6r) and intramembrane (gp130) domains of the IL-6 receptor were cloned in 1988 and 1990, respectively $[137,138]$. IL-6 is the first myokine produced and released into the supernatant when $\mathrm{C} 2 \mathrm{C} 12$ myotubes and skeletal muscle fibers are induced to contract by electrical pulse stimulation $[22,23]$.

Plasma IL-6 levels are relatively higher in elderly subjects compared to those in younger subjects, particularly in men [139]. Many studies have reported that plasma IL-6 levels increase with age [140-143]. Although the mechanism underlying age-related IL-6 upregulation is not fully understood, increases in IL-6 levels affect redox balance, mitochondrial physiology, and satellite cells in skeletal muscle [144-146]. Further studies are required to investigate sgp130 and sIL-6r expression, which is not always consistent with the increase in plasma IL-6 levels during aging.

IL-6 levels increase in urine, but not in plasma, after long-distance running [147]. Steensberg et al. demonstrated that plasma IL-6 levels increase with exercise, which contribute to the maintenance of glucose homeostasis [21]. Since then, many studies have reported increased IL-6 levels in response to exercise. IL-6 mRNA levels increased significantly after a single round of exercise in an in vitro exercise model employing human cultured vastus lateralis cells [148]. However, plasma IL-6 did not change in patients with progressive multiple sclerosis after acute endurance exercise (i.e., arm ergometry, rowing, and bicycle ergometry) [149]. These results indicate that the effects of exercise on IL-6 differ in healthy subjects and in diseased patients, which should be considered in future studies. No changes in baseline IL-6 levels, or those observed in response to different intensities of isovolumetric resistance exercise were observed in a study of elderly ( $\geq 65$ years) men [150]. Furthermore, blood-flow-restricted resistance exercise does not regulate IL-6 expression [151]. In one study, IL-6 mRNA expression increased significantly in healthy men (20.5 \pm 1.5 years) after high-intensity interval training [152]. In another study, patients with a spinal cord injury developed muscle atrophy and sympathetic nervous system dysfunction owing to the lack of an exercise-related IL-6 response [133]. Finally, IL-6 levels increased after acute strenuous exercise, i.e., a wheelchair marathon [153,154]. A recent study showed that plasma IL-6 levels are closely related to obesity, microglial function, and lactate production [155-157]. Pedersen et al. have published several studies on the relationship between exercise and IL-6 levels in great detail $[19,158,159]$.

\subsection{Irisin (Fibronectin Type III Domain Containing 5 [FNDC5])}

Irisin, which is a novel myokine discovered in 2012, is expressed in a PGC- $1 \alpha$-dependent manner to produce FNDC5. This is followed by cleavage of the N-terminal signal peptide and C-terminal hydrophobic domain, resulting in the production of a $12 \mathrm{kDa}$ glycoprotein that is secreted into the bloodstream and is involved in fat metabolism. FNDC5 is predominantly localized in the endoplasmic reticulum [160]. Genomic sequencing analyses indicate that FNDC5 contains six exons and this gene has been mapped to chromosome 1p35.1 [161]. Although the irisin receptor is unknown, irisin is highly conserved in all mammalian species, which suggests highly conserved biological functions [162]. Recently, irisin has been hypothesized to be involved in the downregulation of insulin resistance pathway (ROS $\rightarrow$ p38 MAPK $\rightarrow$ PGC- $1 \alpha \rightarrow$ irisin $\rightarrow$ insulin resistance pathway), which is positively controlled by exercise and negatively controlled by aging [163].

Baseline circulating irisin levels are lower in older than in younger subjects [164]. When plasma irisin concentrations were measured in 715 Korean participants divided into three groups (40s, 50s, and 60s), the lowest concentrations were found in the oldest group [165]. Irisin mRNA expression is significantly lower in old rats with acute liver injury than that in young rats [166]. However, unlike plasma irisin, irisin in the cerebrospinal fluid of humans has been demonstrated to increase 
with age [167], and the shortening of telomere length with aging is negatively correlated with plasma irisin levels [168].

Aerobic exercise, such as running, swimming, and treadmill training, upregulates the expression of irisin at mRNA and protein levels, as well as irisin levels in the plasma, in humans, mice, and rats [169-177]. However, irisin production is higher in cardiac muscle than that in skeletal muscle, which suggests that skeletal muscle is probably not the main source of irisin. Therefore, it is necessary to accurately evaluate how much plasma irisin is secreted from the skeletal muscles [178]. Bubak et al. reported that temperature $\left(33^{\circ} \mathrm{C}\right.$ or $\left.7^{\circ} \mathrm{C}\right)$ during exercise does not affect plasma irisin concentrations, and Fox et al. demonstrated that exercise increases plasma irisin concentrations $[179,180]$. Furthermore, the increase in irisin levels in response to exercise ameliorates the functional impairment of neurons, which suggests the possibility of treating Alzheimer's disease [181-183].

\subsection{Myostatin (Growth/Differentiation Factor-8 [GDF-8])}

Myostatin (GDF-8), a member of the TGF- $\beta$ superfamily, plays an important role in the negative regulation of skeletal muscle growth and is specifically expressed in developmental and adult skeletal muscle [184,185]. Myostatin, inhibited by follistatin, has recently attracted attention as a useful pharmacological target for preserving muscle mass and preventing atrophy [186]. McPherron et al. and Gonzalez-Cadavid et al. isolated and characterized the mouse myostatin and human myostatin genes, respectively $[184,187]$. In one study, plasma myostatin concentration in three groups of subjects (19-35, 60-75, and 76-92 years) were highest in the 76-92-year-old group, which suggests that plasma myostatin could be used as a biomarker for diagnosing age-associated sarcopenia [188].

Resistance training decreases plasma myostatin concentrations in healthy men, and acute resistance exercise decreases myostatin signaling by activating Notch signaling in rats $[189,190]$. Myostatin mRNA and plasma protein levels in rat decrease in response to aerobic exercise, and the same results have been reported in humans [191-194]. Patients with chronic heart failure show an increase in myostatin mRNA and protein; however, they decrease with exercise, indicating a beneficial anti-catabolic effect in patients with chronic heart failure $[195,196]$. The same result has been observed in patients with chronic kidney disease $[197,198]$. A combination of myostatin inhibition and endurance training is particularly effective for treating lipidomic abnormalities [199]. In some cases, different results have been reported depending on age, sex, exercise type (aerobic or anaerobic), and localization (plasma or muscle). The complex in vivo roles of myostatin have been studied and speculated upon [107,200-203], and it is an interesting target candidate for further research.

\subsection{Stromal Cell-Derived Factor 1 (SDF-1)}

The expression of SDF-1-also called CXC motif chemokine ligand 12 (CXCL12), intercrine reduced in hepatomas (IRH), and pre-B cell growth-stimulating factor-is expressed in many cell types (i.e., fibroblasts, myoblasts, muscle fibers) [204]. This chemokine was originally described as a B-cell precursor stimulating growth factor secreted by a bone marrow stromal cell line [205]. CXCR4 and CXCR7 are the primary physiological receptors of SDF-1 [206,207], and the gene coding for this protein is located on chromosome 10q11.1 [208,209]. SDF-1-CXCR4 signaling occurs in the mesenchyme of limbs during early development and is directly responsible for the development of appropriately sized muscles [210], which indicates its important role in skeletal muscle regeneration [211,212].

Alzheimer's disease (AD) is the most common form of dementia in the elderly. The Tg2576 mouse model of $\mathrm{AD}$, in which the gene encoding human amyloid precursor protein is expressed, is an important $\mathrm{AD}$ animal model. CXCL12 levels are lower in AD patients compared to those in heathy controls, which suggests that CXCL12 is closely associated with aging [213]. The numbers of senescent fibroblasts increase in aged pigmented skin, where SDF-1 mRNA expression is reduced 3.55-fold [214]. SDF-1 expression is downregulated in the wounded skin of old mice, just as it is suppressed in an age-dependent manner in human skin [215]. Periyasamy-Thandavan et al. reported decreases in SDF-1 concentrations and bioactivity in the bone marrow interstitial fluid of older humans 
(18-40 vs. $60-85$ years) and mice (3 vs. 22 months) [216]. SDF-1 expression is negatively regulated by miR-141-3p in an age-dependent manner [216].

The concentration of plasma CXCL12 is enhanced in response to training on a bicycle ergometer [217], and rounds of acute exercise increase CXCL12 mRNA expression in the skeletal muscle [218]. Four weeks of treadmill running produced a 3-fold increase in CXCL12 mRNA and protein levels in the gastrocnemius of rats, which activated mTOR-p70S6K signaling to induce autophagy [219]. When $\mathrm{C} 2 \mathrm{C} 12$ myotubes are mechanically stretched, CXCL12 production and release increase results in the activation of endothelial cell proliferation. CXCL12 KO (CXCL12-/-) mice suffer from severely impaired angiogenesis in skeletal muscles [220].

\subsection{Sestrin}

Sestrin was first discovered in 1994 as a target of the tumor suppressor $p 53$ and was referred to as p53-activated gene 26 (PA26). The gene coding for sestrin is located on chromosome 6q21 [221,222]. In mammalian cells, three different sestrin isoforms, which share high sequence homology, are encoded by genes located on different chromosomes, Sestrin1 on chromosome 6, Sestrin 2 on chromosome 1, and Sestrin3 on chromosome 11 [223]. Sestrin acts as an intracellular leucine sensor to negatively regulate the target of rapamycin complex 1 (TORC-1) signaling by activating AMP-dependent protein kinase (AMPK), which prevents the development of sarcopenia and extends the life span [224]. Pathophysiological stressors, such as DNA damage and oxidative stress, upregulate sestrin expression, which negatively regulates aging by activating the AMPK/autophagy pathway and inhibiting the TORC1 signaling [225].

Sestrin2 is downregulated in the gastrocnemius muscle of old mice, which is characterized by a marginal reduction in sestrin 2 mRNA and a significant reduction in sestrin 2 protein [226]. The expression of cardiac sestrin2 also decreases with age [227]. In a study of 31 young (18-30 years) and 73 older (65-80 years) men without specific diseases in New Zealand and Australia, plasma sestrin 1 and sestrin3 levels were found to decrease with age [228]. Rai et al. reported that concentrations of plasma sestrin1 and sestrin2 decrease significantly in elderly subjects [229]. An early study on Drosophila sestrin showed that inactivation of sestrin results in a significant increase in the development of age-associated pathologies, such as cancer, diabetes, muscle dystrophy, and chronic inflammation [230].

mRNA expression and plasma and skeletal muscle levels of sestrin1 and sestrin2 increase simultaneously after exercise [231]. Sestrin2 protein expression increases in response to aerobic exercise (i.e., swimming) in old mice [226]. Phosphorylation of sestrin2 in response to exercise induces p62 dephosphorylation, thereby inducing oxidative stress and selective autophagy [232]. Exercise-induced sestrin has been demonstrated to interact with AMPK, although the precise molecular mechanism remains unclear. Thus, sestrin is beneficial and may provide new insight into age-associated metabolic diseases [233-235].

\subsection{Secreted Protein, Acidic, Rich in Cysteine (SPARC; Osteonectin/Basement-Membrane Protein 40)}

In 1989, the human SPARC was first demonstrated to be located on chromosome 5q33.1 [236], and since then, it has been confirmed that the SPARC protein functions in a $\mathrm{Ca}^{2+}$-ion-dependent manner [237]. SPARC is a $43 \mathrm{kDa}$ secretory matricellular glycoprotein that has multiple biological functions, including tumor-suppressing activity, cell differentiation, and cell adhesion in several organs and cell types [238-240]. SPARC was first recognized as a myokine in 2013 as a result of cell-stretching stimulation experiments on C2C12 myocytes [241].

In experiments on young ( $4-5$ months) and old ( $>21$ months) male rats, SPARC expression unchanged in skeletal muscle progenitor cells of the old rats, whereas SPARC protein expression decreased in the same rats [242]. Silencing of SPARC using siRNA led to a direct reduction in myofibril diameter. Therefore, age-related decreased expression of SPARC may induce sarcopenia 
development $[243,244]$. Other studies have reported that SPARC expression generally decreases with age (7-10 vs. 24-30 weeks) in the tibialis anterior of wild mice [245].

In 2013, it was first demonstrated experimentally that aerobic exercise (i.e., cycling) increases SPARC secretion twofold in human plasma, and the same result was obtained in C2C12 myoblasts stimulated with electric pulses [241]. Catoire et al. identified SPARC as a myokine whose expression is upregulated in response to acute exercise [246]. It has been suggested that SPARC is a tumor suppressor, as changes in SPARC expression affect sensitivity to radiation and chemotherapy in patients with colorectal cancer $[247,248]$. It has recently been reported that exercise-induced SPARC expression suppresses cancer, as azoxymethane (AOM)-induced colonic tumorigenesis is inhibited by exercise, but not in SPARC(-/-) mice [241]. However, plasma SPARC levels do not increase in response to a single brief supramaximal cycle sprint, which suggests that the SPARC in the plasma originates from organs other than skeletal muscle, so the origin of SPARC in the blood must be clarified [249]. However, SPARC has gained attention as a myokine because of its cancer-suppressing effects [250].

\subsection{Vascular Endothelial Growth Factor A (VEGF-A)}

VEGF-A, first discovered in 1983 [251], is encoded by a gene located on chromosome 6p21.1; the cDNA encoding VEGF-A was isolated in 1989 [252]. VEGF-A is a secreted, $46 \mathrm{kDa}$ homodimer glycoprotein containing a highly conserved receptor-binding cysteine-knot structure. VEGF-A is one of the most important factors in the growth and survival of skeletal muscle in humans and animals [253].

We conducted a bibliographic search on whether physical exercise affects plasma VEGF-A concentration in the elderly; we referred to the 10 most relevant (of the 574) articles published between 1990 and 2013. Although four articles confirmed increases in plasma VEGF-A concentration after physical exercise, the other six articles found no changes [254]. The downregulation of VEGF-A mRNA and protein expression has been reported in aged human dermal microvascular endothelial cells [255] and in aged skeletal muscle obtained from the human vastus lateralis [256]. Experiments using VEGF-A KO (VEGF-/-) mice have revealed reduced gastrocnemius muscle mass (by 80-90\%) [257].

However, various studies have shown that physical exercise upregulates VEGF-A. VEGF-A mRNA and protein levels increased twofold in skeletal muscle after one-legged knee extension training (anaerobic exercise) for 8 weeks in patients with heart failure [258]. The increase in reactive oxygen species (ROS) due to exercise increases the expression of PGC- $1 \alpha$, resulting in upregulation of VEGF-A expression in skeletal muscle [259]. In one study, when mice were made to run on wheels (aerobic exercise) for 14 days, VEGF-A expression increased by $34.6 \%$ in the skeletal plantaris, but VEGF-/- mice did not recover after exercise training [260].

\section{Discussion}

The most reasonable way to maintain healthy muscles is to increase muscle mass through appropriate physical exercise and leisure-time physical activity (LTPA), such as walking, dancing, gardening, hiking, and swimming. Many recent studies have proved that maintaining high-quality muscles through appropriate physical activity helps prolong life via various mechanisms [261,262].

Many studies have demonstrated the beneficial effects of physical activity on the physical health of the elderly as a solution for preventing aging-related diseases [263-266]. Generally, exercise burns fat, preventing the accumulation of fat in the body. This reduces the likelihood that controlling metabolic risk factors such as high triglyceride, low high-density lipoprotein (HDL) cholesterol level, and high blood pressure would result in reduced incidence of metabolic diseases to which the elderly are vulnerable. Many studies have demonstrated that physical activity prevents metabolic diseases and contributes to a prolonged life span [261,262]. Physical exercise enhances immunity and improves memory, which is beneficial in Alzheimer's disease [267,268]. LTPA also decreases the risks of 13 types of cancer [269]. Maintaining the thigh circumference, a typical skeletal muscle, reduces the risks of developing heart disease and premature death [270]. Indeed, physically active people are at a lower risk of all-cause mortality than their physically inactive counterparts [271]. In line with previous 
research, many experimental studies have proved the positive impact of physical activity on cognitive ability in the elderly [272-274]. Overall, physical activity has a direct positive effect on maintaining the health of the elderly.

The biggest takeaway of our review is that both aerobic and anaerobic exercises exert positive effects on skeletal muscles by releasing various myokines that are beneficial to the elderly. Given that most studies on LTPA in the elderly have focused on aerobic exercises [275-277], it is worth broadening the scope of research by examining the need for anaerobic exercise. The incidence of typical muscle diseases in the elderly could be attributed to normal food intake without ATP production in the body, which results in an age-related decline in skeletal muscle mass and strength (sarcopenia). However, the exact cause and treatment are not fully understood. Therefore, further research should focus on myokines whose expression is exclusively induced by anaerobic exercise. Searching for the cause of skeletal muscle loss and its biomarkers will provide clues to the prevention of geriatric diseases and development of new treatments. This review provides scientific evidence that can be used by health practitioners to develop and promote exercise programs or interventions that maintain the balance between aerobic and anaerobic exercises for the elderly. Skeletal muscle loss in the elderly is not just a personal problem but also a social problem. Considering the huge medical costs associated with the treatment of sarcopenia and osteoporotic fractures $[278,279]$ — which impose a huge tax burden on all members of society-recreational therapists, researchers, policymakers, and clinicians are urged to work together to improve the health of the elderly.

\section{Conclusions}

Myokines are secreted in response to skeletal muscle contractions during exercise and are promising anti-aging molecules due to their benefits in age-related diseases. Our review provides a conceptual basis for understanding different exercise-induced myokines and their therapeutic roles in helping the elderly remain healthy. We found that myokines are produced in response to regular exercise and play a key role in preventing or attenuating aging-related disease, such as dementia, obesity, diabetes, and cardiovascular and metabolic diseases. Although the 13 myokines reviewed are all stimulated by exercise, each has unique characteristics. In brief, apelin is an anti-aging factor and has positive effects on hypertension and ischemia-reperfusion injury when combined with exercise. BAIBA prevents metabolic diseases by acting as an osteocyte survival factor, protecting against mitochondrial breakdown, and attenuating bone and skeletal muscle loss. BMP-7 is an important factor in bone formation and skeletal muscle mass maintenance. Decorin, IGF-1, and SDF-1 have positive effects on tendon strength, bone and tissue development, and skeletal muscle regeneration, respectively. IL-15 facilitates fibroblast collagen synthesis and cell proliferation. IL- 6 contributes to the maintenance of glucose homeostasis, obesity regulation, microglial function, and lactate production. Irisin might become a treatment for Alzheimer's disease because of its positive influence on neuron functional impairment. The most interesting is myostatin. Unlike the other myokines, exercise reduces its secretion. It is beneficial in chronic heart failure, chronic kidney disease, and lipidomic abnormalities. Sestrin helps prevent the development of age-associated metabolic diseases and sarcopenia. SPARC, which is increased by aerobic exercise, has potential as a cancer treatment. VEGF-A, which is upregulated by both anaerobic and aerobic exercise, is involved in the growth and survival of skeletal muscle.

Author Contributions: J.H.K., K.M.M. and K.-W.M.; formal analysis, J.H.K. and K.M.M.; writing-original draft, J.H.K.; writing-review and editing, K.M.M. All authors have read and agreed to the published version of the manuscript.

Funding: This research received no external funding

Conflicts of Interest: The authors have no conflicts of interest to declare. 


\section{References}

1. Kalache, A.; Gatti, A. Active ageing: A policy framework. Adv. Gerontol. 2003, 11, 7-18.

2. Mitchell, W.K.; Williams, J.; Atherton, P.; Larvin, M.; Lund, J.; Narici, M. Sarcopenia, dynapenia, and the impact of advancing age on human skeletal muscle size and strength; a quantitative review. Front. Physiol. 2012, 3, 260. [CrossRef]

3. Zierer, J.; Pallister, T.; Tsai, P.C.; Krumsiek, J.; Bell, J.T.; Lauc, G.; Spector, T.D.; Menni, C.; Kastenmuller, G. Exploring the molecular basis of age-related disease comorbidities using a multi-omics graphical model. Sci. Rep. 2016, 6, 37646. [CrossRef] [PubMed]

4. Department of Health, P.A., Health Improvement and Protection. Start Active, Stay Active: A Report on Physical Activity for Health from the Four Home Countries' Chief Medical Officers. Available online: https://assets.publishing.service.gov.uk/government/uploads/system/uploads/attachment_data/file/ 830943/withdrawn_dh_128210.pdf (accessed on 9 September 2020).

5. de Sire, R.; Rizzatti, G.; Ingravalle, F.; Pizzoferrato, M.; Petito, V.; Lopetuso, L.; Graziani, C.; de Sire, A.; Mentella, M.C.; Mele, M.C.; et al. Skeletal muscle-gut axis: Emerging mechanisms of sarcopenia for intestinal and extra intestinal diseases. Minerva Gastroenterol. Dietol. 2018, 64, 351-362. [CrossRef] [PubMed]

6. Roubenoff, R.; Hughes, V.A. Sarcopenia: Current concepts. J. Gerontol. A Biol. Sci. Med. Sci. 2000, 55, M716-M724. [CrossRef] [PubMed]

7. Gianoudis, J.; Bailey, C.A.; Daly, R.M. Associations between sedentary behaviour and body composition, muscle function and sarcopenia in community-dwelling older adults. Osteoporos Int. 2015, 26, 571-579. [CrossRef]

8. Critchley, M. The neurology of old age. Lancet 1931, 217, 1119-1127. [CrossRef]

9. Arango-Lopera, V.E.; Arroyo, P.; Gutierrez-Robledo, L.M.; Perez-Zepeda, M.U.; Cesari, M. Mortality as an adverse outcome of sarcopenia. J. Nutr. Health Aging 2013, 17, 259-262. [CrossRef]

10. Brady, A.O.; Straight, C.R.; Evans, E.M. Body composition, muscle capacity, and physical function in older adults: An integrated conceptual model. J. Aging Phys. Act. 2014, 22, 441-452. [CrossRef]

11. Trombetti, A.; Reid, K.F.; Hars, M.; Herrmann, F.R.; Pasha, E.; Phillips, E.M.; Fielding, R.A. Age-associated declines in muscle mass, strength, power, and physical performance: Impact on fear of falling and quality of life. Osteoporos Int. 2016, 27, 463-471. [CrossRef]

12. Global Health Risks: Mortality and Burden of Disease Attributable to Selected Major Risks. Available online: https://apps.who.int/iris/handle/10665/44203 (accessed on 29 September 2020).

13. Frontera, W.R.; Ochala, J. Skeletal muscle: A brief review of structure and function. Calcif. Tissue Int. 2015, 96, 183-195. [CrossRef] [PubMed]

14. Broholm, C.; Mortensen, O.H.; Nielsen, S.; Akerstrom, T.; Zankari, A.; Dahl, B.; Pedersen, B.K. Exercise induces expression of leukaemia inhibitory factor in human skeletal muscle. J. Physiol. 2008, 586, 2195-2201. [CrossRef] [PubMed]

15. Ouchi, N.; Oshima, Y.; Ohashi, K.; Higuchi, A.; Ikegami, C.; Izumiya, Y.; Walsh, K. Follistatin-like 1, a secreted muscle protein, promotes endothelial cell function and revascularization in ischemic tissue through a nitric-oxide synthase-dependent mechanism. J. Biol. Chem. 2008, 283, 32802-32811. [CrossRef] [PubMed]

16. Pedersen, B.K.; Akerstrom, T.C.; Nielsen, A.R.; Fischer, C.P. Role of myokines in exercise and metabolism. J. Appl. Physiol. 2007, 103, 1093-1098. [CrossRef]

17. Pal, M.; Febbraio, M.A.; Whitham, M. From cytokine to myokine: The emerging role of interleukin-6 in metabolic regulation. Immunol. Cell Biol. 2014, 92, 331-339. [CrossRef]

18. Bruunsgaard, H.; Galbo, H.; Halkjaer-Kristensen, J.; Johansen, T.L.; MacLean, D.A.; Pedersen, B.K. Exercise-induced increase in serum interleukin-6 in humans is related to muscle damage. J. Physiol. 1997, 499 Pt 3, 833-841. [CrossRef]

19. Pedersen, B.K.; Febbraio, M.A. Muscle as an endocrine organ: Focus on muscle-derived interleukin-6. Physiol. Rev. 2008, 88, 1379-1406. [CrossRef]

20. Jonsdottir, I.H.; Schjerling, P.; Ostrowski, K.; Asp, S.; Richter, E.A.; Pedersen, B.K. Muscle contractions induce interleukin-6 mRNA production in rat skeletal muscles. J. Physiol. 2000, 528 Pt 1, 157-163. [CrossRef]

21. Steensberg, A.; van Hall, G.; Osada, T.; Sacchetti, M.; Saltin, B.; Klarlund Pedersen, B. Production of interleukin-6 in contracting human skeletal muscles can account for the exercise-induced increase in plasma interleukin-6. J. Physiol. 2000, 529 Pt 1, 237-242. [CrossRef] 
22. Nedachi, T.; Fujita, H.; Kanzaki, M. Contractile C2C12 myotube model for studying exercise-inducible responses in skeletal muscle. Am. J. Physiol. Endocrinol. Metab. 2008, 295, E1191-E1204. [CrossRef]

23. Farmawati, A.; Kitajima, Y.; Nedachi, T.; Sato, M.; Kanzaki, M.; Nagatomi, R. Characterization of contraction-induced IL-6 up-regulation using contractile C2C12 myotubes. Endocr. J. 2013, 60, 137-147. [CrossRef] [PubMed]

24. Whitham, M.; Chan, M.H.; Pal, M.; Matthews, V.B.; Prelovsek, O.; Lunke, S.; El-Osta, A.; Broenneke, H.; Alber, J.; Bruning, J.C.; et al. Contraction-induced interleukin-6 gene transcription in skeletal muscle is regulated by c-Jun terminal kinase/activator protein-1. J. Biol. Chem. 2012, 287, 10771-10779. [CrossRef]

25. Furuichi, Y.; Manabe, Y.; Takagi, M.; Aoki, M.; Fujii, N.L. Evidence for acute contraction-induced myokine secretion by C2C12 myotubes. PLoS ONE 2018, 13, e0206146. [CrossRef] [PubMed]

26. Pourteymour, S.; Eckardt, K.; Holen, T.; Langleite, T.; Lee, S.; Jensen, J.; Birkeland, K.I.; Drevon, C.A.; Hjorth, M. Global mRNA sequencing of human skeletal muscle: Search for novel exercise-regulated myokines. Mol. Metab. 2017, 6, 352-365. [CrossRef] [PubMed]

27. Leal, L.G.; Lopes, M.A.; Batista, M.L., Jr. Physical exercise-induced myokines and muscle-adipose tissue crosstalk: A review of current knowledge and the implications for health and metabolic diseases. Front. Physiol. 2018, 9, 1307. [CrossRef]

28. Fiuza-Luces, C.; Santos-Lozano, A.; Joyner, M.; Carrera-Bastos, P.; Picazo, O.; Zugaza, J.L.; Izquierdo, M.; Ruilope, L.M.; Lucia, A. Exercise benefits in cardiovascular disease: Beyond attenuation of traditional risk factors. Nat. Rev. Cardiol. 2018, 15, 731-743. [CrossRef]

29. Tatemoto, K.; Hosoya, M.; Habata, Y.; Fujii, R.; Kakegawa, T.; Zou, M.X.; Kawamata, Y.; Fukusumi, S.; Hinuma, S.; Kitada, C.; et al. Isolation and characterization of a novel endogenous peptide ligand for the human APJ receptor. Biochem. Biophys. Res. Commun. 1998, 251, 471-476. [CrossRef]

30. Lee, D.K.; Cheng, R.; Nguyen, T.; Fan, T.; Kariyawasam, A.P.; Liu, Y.; Osmond, D.H.; George, S.R.; O’Dowd, B.F. Characterization of apelin, the ligand for the APJ receptor. J. Neurochem. 2000, 74, 34-41. [CrossRef]

31. Habata, Y.; Fujii, R.; Hosoya, M.; Fukusumi, S.; Kawamata, Y.; Hinuma, S.; Kitada, C.; Nishizawa, N.; Murosaki, S.; Kurokawa, T.; et al. Apelin, the natural ligand of the orphan receptor APJ, is abundantly secreted in the colostrum. Biochim. Biophys. Acta 1999, 1452, 25-35. [CrossRef]

32. Tatemoto, K.; Takayama, K.; Zou, M.X.; Kumaki, I.; Zhang, W.; Kumano, K.; Fujimiya, M. The novel peptide apelin lowers blood pressure via a nitric oxide-dependent mechanism. Regul. Pept. 2001, 99, 87-92. [CrossRef]

33. Szokodi, I.; Tavi, P.; Foldes, G.; Voutilainen-Myllyla, S.; Ilves, M.; Tokola, H.; Pikkarainen, S.; Piuhola, J.; Rysa, J.; Toth, M.; et al. Apelin, the novel endogenous ligand of the orphan receptor APJ, regulates cardiac contractility. Circ. Res. 2002, 91, 434-440. [CrossRef] [PubMed]

34. Zhang, L.; Takara, K.; Yamakawa, D.; Kidoya, H.; Takakura, N. Apelin as a marker for monitoring the tumor vessel normalization window during antiangiogenic therapy. Cancer Sci. 2016, 107, 36-44. [CrossRef] [PubMed]

35. Zhang, J.; Liu, Q.; Fang, Z.; Hu, X.; Huang, F.; Tang, L.; Zhou, S. Hypoxia induces the proliferation of endothelial progenitor cells via upregulation of Apelin/APLNR/MAPK signaling. Mol. Med. Rep. 2016, 13, 1801-1806. [CrossRef]

36. Boucher, J.; Masri, B.; Daviaud, D.; Gesta, S.; Guigne, C.; Mazzucotelli, A.; Castan-Laurell, I.; Tack, I.; Knibiehler, B.; Carpene, C.; et al. Apelin, a newly identified adipokine up-regulated by insulin and obesity. Endocrinology 2005, 146, 1764-1771. [CrossRef]

37. Li, L.; Yang, G.; Li, Q.; Tang, Y.; Yang, M.; Yang, H.; Li, K. Changes and relations of circulating visfatin, apelin, and resistin levels in normal, impaired glucose tolerance, and type 2 diabetic subjects. Exp. Clin. Endocrinol. Diabetes 2006, 114, 544-548. [CrossRef] [PubMed]

38. Masoumi, J.; Jafarzadeh, A.; Khorramdelazad, H.; Abbasloui, M.; Abdolalizadeh, J.; Jamali, N. Role of Apelin/APJ axis in cancer development and progression. Adv. Med. Sci. 2020, 65, 202-213. [CrossRef]

39. Besse-Patin, A.; Montastier, E.; Vinel, C.; Castan-Laurell, I.; Louche, K.; Dray, C.; Daviaud, D.; Mir, L.; Marques, M.A.; Thalamas, C.; et al. Effect of endurance training on skeletal muscle myokine expression in obese men: Identification of apelin as a novel myokine. Int. J. Obes. 2014, 38, 707-713. [CrossRef]

40. Vinel, C.; Lukjanenko, L.; Batut, A.; Deleruyelle, S.; Pradere, J.P.; Le Gonidec, S.; Dortignac, A.; Geoffre, N.; Pereira, O.; Karaz, S.; et al. The exerkine apelin reverses age-associated sarcopenia. Nat. Med. 2018, 24, 1360-1371. [CrossRef] 
41. Rai, R.; Ghosh, A.K.; Eren, M.; Mackie, A.R.; Levine, D.C.; Kim, S.Y.; Cedernaes, J.; Ramirez, V.; Procissi, D.; Smith, L.H.; et al. Downregulation of the apelinergic axis accelerates aging, whereas its systemic restoration improves the mammalian healthspan. Cell Rep. 2017, 21, 1471-1480. [CrossRef]

42. Zhang, J.; Ren, C.X.; Qi, Y.F.; Lou, L.X.; Chen, L.; Zhang, L.K.; Wang, X.; Tang, C. Exercise training promotes expression of apelin and APJ of cardiovascular tissues in spontaneously hypertensive rats. Life Sci. 2006, 79, 1153-1159. [CrossRef]

43. Kwak, S.E.; Cho, S.C.; Bae, J.H.; Lee, J.; Shin, H.E.; Zhang, D.D.; Lee, Y.I.; Song, W. Effects of exercise-induced apelin on muscle function and cognitive function in aged mice. Exp. Gerontol. 2019, 127, 110710. [CrossRef] [PubMed]

44. Nazari, A.; Chehelcheraghi, F. Using Apelin and exercise to protect the cardiac cells: Synergic effect in ischemia reperfusion injuries treatment in rats. Bratisl. Lek. Listy 2020, 121, 14-21. [CrossRef] [PubMed]

45. Crumpler, H.R.; Dent, C.E.; Harris, H.; Westall, R.G. $\beta$-Aminoisobutyric acid ( $\alpha$-methyl- $\beta$-alanine); a new amino-acid obtained from human urine. Nature 1951, 167, 307-308. [CrossRef] [PubMed]

46. Roberts, L.D.; Bostrom, P.; O'Sullivan, J.F.; Schinzel, R.T.; Lewis, G.D.; Dejam, A.; Lee, Y.K.; Palma, M.J.; Calhoun, S.; Georgiadi, A.; et al. beta-Aminoisobutyric acid induces browning of white fat and hepatic beta-oxidation and is inversely correlated with cardiometabolic risk factors. Cell Metab. 2014, 19, 96-108. [CrossRef]

47. Schnyder, S.; Handschin, C. Skeletal muscle as an endocrine organ: PGC-1alpha, myokines and exercise. Bone 2015, 80, 115-125. [CrossRef] [PubMed]

48. Kammoun, H.L.; Febbraio, M.A. Come on BAIBA light my fire. Cell Metab. 2014, 19, 1-2. [CrossRef]

49. Shi, C.X.; Zhao, M.X.; Shu, X.D.; Xiong, X.Q.; Wang, J.J.; Gao, X.Y.; Chen, Q.; Li, Y.H.; Kang, Y.M.; Zhu, G.Q. $\beta$-aminoisobutyric acid attenuates hepatic endoplasmic reticulum stress and glucose/lipid metabolic disturbance in mice with type 2 diabetes. Sci. Rep. 2016, 6, 21924. [CrossRef]

50. Tanianskii, D.A.; Jarzebska, N.; Birkenfeld, A.L.; O'Sullivan, J.F.; Rodionov, R.N. Beta-aminoisobutyric acid as a novel regulator of carbohydrate and lipid metabolism. Nutrients 2019, 11, 524. [CrossRef]

51. Fazelzadeh, P.; Hangelbroek, R.W.; Tieland, M.; de Groot, L.C.; Verdijk, L.B.; van Loon, L.J.; Smilde, A.K.; Alves, R.D.; Vervoort, J.; Muller, M.; et al. The muscle metabolome differs between healthy and frail older adults. J. Proteome Res. 2016, 15, 499-509. [CrossRef]

52. Ginter, E.; Simko, V. Recent data on obesity research: Beta-aminoisobutyric acid. Bratisl. Lek. Listy 2014, 115, 492-493. [CrossRef]

53. Hangelbroek, R.W.; Fazelzadeh, P.; Tieland, M.; Boekschoten, M.V.; Hooiveld, G.J.; van Duynhoven, J.P.; Timmons, J.A.; Verdijk, L.B.; de Groot, L.C.; van Loon, L.J.; et al. Expression of protocadherin gamma in skeletal muscle tissue is associated with age and muscle weakness. J. Cachexia Sarcopenia Muscle 2016, 7, 604-614. [CrossRef] [PubMed]

54. Kitase, Y.; Vallejo, J.A.; Gutheil, W.; Vemula, H.; Jahn, K.; Yi, J.; Zhou, J.; Brotto, M.; Bonewald, L.F. $\beta$-Aminoisobutyric acid, l-BAIBA, is a muscle-derived osteocyte survival factor. Cell Rep. 2018, 22, 1531-1544. [CrossRef] [PubMed]

55. Bonewald, L. Use it or lose it to age: A review of bone and muscle communication. Bone 2019, 120, $212-218$. [CrossRef] [PubMed]

56. Wang, Z.; Bian, L.; Mo, C.; Shen, H.; Zhao, L.J.; Su, K.J.; Kukula, M.; Lee, J.T.; Armstrong, D.W.; Recker, R.; et al. Quantification of aminobutyric acids and their clinical applications as biomarkers for osteoporosis. Commun. Biol. 2020, 3, 39. [CrossRef]

57. Hatazawa, Y.; Senoo, N.; Tadaishi, M.; Ogawa, Y.; Ezaki, O.; Kamei, Y.; Miura, S. Metabolomic analysis of the skeletal muscle of mice overexpressing PGC-1alpha. PLoS ONE 2015, 10, e0129084. [CrossRef]

58. Stautemas, J.; Van Kuilenburg, A.B.P.; Stroomer, L.; Vaz, F.; Blancquaert, L.; Lefevere, F.B.D.; Everaert, I.; Derave, W. Acute aerobic exercise leads to increased plasma levels of R- and S- $\beta$-aminoisobutyric acid in humans. Front. Physiol. 2019, 10, 1240. [CrossRef]

59. Kamei, Y.; Hatazawa, Y.; Uchitomi, R.; Yoshimura, R.; Miura, S. Regulation of skeletal muscle function by amino acids. Nutrients 2020, 12, 261. [CrossRef]

60. Short, K.R.; Chadwick, J.Q.; Teague, A.M.; Tullier, M.A.; Wolbert, L.; Coleman, C.; Copeland, K.C. Effect of obesity and exercise training on plasma amino acids and amino metabolites in American Indian adolescents. J. Clin. Endocrinol. Metab. 2019, 104, 3249-3261. [CrossRef] 
61. Molfino, A.; Amabile, M.I.; Ammann, T.; Farcomeni, A.; Lionetto, L.; Simmaco, M.; Lai, S.; Laviano, A.; Rossi Fanelli, F.; Chiappini, M.G.; et al. The metabolite beta-aminoisobutyric acid and physical inactivity among hemodialysis patients. Nutrition 2017, 34, 101-107. [CrossRef]

62. Molfino, A.; Amabile, M.I.; Ammann, T.; Lai, S.; Grosso, A.; Lionetto, L.; Spagnoli, A.; Simmaco, M.; Monti, M.; Laviano, A.; et al. Longitudinal physical activity change during hemodialysis and its association with body composition and plasma BAIBA levels. Front. Physiol. 2019, 10, 805. [CrossRef]

63. Urist, M.R. Bone: Formation by autoinduction. Science 1965, 150, 893-899. [CrossRef] [PubMed]

64. Mitu, G.; Hirschberg, R. Bone morphogenetic protein-7 (BMP7) in chronic kidney disease. Front. Biosci. 2008, 13, 4726-4739. [CrossRef] [PubMed]

65. Pesonen, E.; Merritt, A.T.; Heldt, G.; Sahn, D.J.; Elias, W.; Tikkanen, I.; Fyhrquist, F.; Andersson, S. Correlation of patent ductus arteriosus shunting with plasma atrial natriuretic factor concentration in preterm infants with respiratory distress syndrome. Pediatr. Res. 1990, 27, 137-139. [CrossRef]

66. Ozkaynak, E.; Rueger, D.C.; Drier, E.A.; Corbett, C.; Ridge, R.J.; Sampath, T.K.; Oppermann, H. OP-1 cDNA encodes an osteogenic protein in the TGF-beta family. EMBO J. 1990, 9, 2085-2093. [CrossRef] [PubMed]

67. Hahn, G.V.; Cohen, R.B.; Wozney, J.M.; Levitz, C.L.; Shore, E.M.; Zasloff, M.A.; Kaplan, F.S. A bone morphogenetic protein subfamily: Chromosomal localization of human genes for BMP5, BMP6, and BMP7. Genomics 1992, 14, 759-762. [CrossRef]

68. Ripamonti, U.; Reddi, A.H. Tissue engineering, morphogenesis, and regeneration of the periodontal tissues by bone morphogenetic proteins. Crit. Rev. Oral Biol. Med. 1997, 8, 154-163. [CrossRef]

69. Chen, D.; Zhao, M.; Mundy, G.R. Bone morphogenetic proteins. Growth Fact. 2004, 22, 233-241. [CrossRef]

70. Schulz, T.J.; Huang, T.L.; Tran, T.T.; Zhang, H.; Townsend, K.L.; Shadrach, J.L.; Cerletti, M.; McDougall, L.E.; Giorgadze, N.; Tchkonia, T.; et al. Identification of inducible brown adipocyte progenitors residing in skeletal muscle and white fat. Proc. Natl. Acad. Sci. USA 2011, 108, 143-148. [CrossRef]

71. Saini, S.; Duraisamy, A.J.; Bayen, S.; Vats, P.; Singh, S.B. Role of BMP7 in appetite regulation, adipogenesis, and energy expenditure. Endocrine 2015, 48, 405-409. [CrossRef]

72. Chubinskaya, S.; Kumar, B.; Merrihew, C.; Heretis, K.; Rueger, D.C.; Kuettner, K.E. Age-related changes in cartilage endogenous osteogenic protein-1 (OP-1). Biochim. Biophys. Acta 2002, 1588, 126-134. [CrossRef]

73. Kim, J.S.; Lee, Y.H.; Yi, H.K. Gradual downhill running improves age-related skeletal muscle and bone weakness: Implication of autophagy and bone morphogenetic proteins. Exp. Physiol. 2016, 101, 1528-1540. [CrossRef] [PubMed]

74. Merrihew, C.; Kumar, B.; Heretis, K.; Rueger, D.C.; Kuettner, K.E.; Chubinskaya, S. Alterations in endogenous osteogenic protein-1 with degeneration of human articular cartilage. J. Orthop. Res. 2003, 21, 899-907. [CrossRef]

75. Loeser, R.F.; Im, H.J.; Richardson, B.; Lu, Q.; Chubinskaya, S. Methylation of the OP-1 promoter: Potential role in the age-related decline in OP-1 expression in cartilage. Osteoarthr. Cartil. 2009, 17, 513-517. [CrossRef] [PubMed]

76. Yeh, L.C.; Tsai, A.D.; Lee, J.C. Osteogenic protein-1 (OP-1, BMP-7) induces osteoblastic cell differentiation of the pluripotent mesenchymal cell line C2C12. J. Cell. Biochem. 2002, 87, 292-304. [CrossRef] [PubMed]

77. Winbanks, C.E.; Chen, J.L.; Qian, H.; Liu, Y.; Bernardo, B.C.; Beyer, C.; Watt, K.I.; Thomson, R.E.; Connor, T.; Turner, B.J.; et al. The bone morphogenetic protein axis is a positive regulator of skeletal muscle mass. J. Cell Biol. 2013, 203, 345-357. [CrossRef] [PubMed]

78. Nam, J.; Perera, P.; Rath, B.; Agarwal, S. Dynamic regulation of bone morphogenetic proteins in engineered osteochondral constructs by biomechanical stimulation. Tissue Eng. Part A 2013, 19, 783-792. [CrossRef] [PubMed]

79. Rocha-Rodrigues, S.; Rodriguez, A.; Gouveia, A.M.; Goncalves, I.O.; Becerril, S.; Ramirez, B.; Beleza, J.; Fruhbeck, G.; Ascensao, A.; Magalhaes, J. Effects of physical exercise on myokines expression and brown adipose-like phenotype modulation in rats fed a high-fat diet. Life Sci. 2016, 165, 100-108. [CrossRef] [PubMed]

80. Vetter, U.; Vogel, W.; Just, W.; Young, M.F.; Fisher, L.W. Human decorin gene: Intron-exon junctions and chromosomal localization. Genomics 1993, 15, 161-168. [CrossRef]

81. Droguett, R.; Cabello-Verrugio, C.; Riquelme, C.; Brandan, E. Extracellular proteoglycans modify TGF-beta bio-availability attenuating its signaling during skeletal muscle differentiation. Matrix Biol. 2006, 25, 332-341. [CrossRef] 
82. Kanzleiter, T.; Rath, M.; Gorgens, S.W.; Jensen, J.; Tangen, D.S.; Kolnes, A.J.; Kolnes, K.J.; Lee, S.; Eckel, J.; Schurmann, A.; et al. The myokine decorin is regulated by contraction and involved in muscle hypertrophy. Biochem. Biophys. Res. Commun. 2014, 450, 1089-1094. [CrossRef]

83. Vuillermoz, B.; Wegrowski, Y.; Contet-Audonneau, J.L.; Danoux, L.; Pauly, G.; Maquart, F.X. Influence of aging on glycosaminoglycans and small leucine-rich proteoglycans production by skin fibroblasts. Mol. Cell. Biochem. 2005, 277, 63-72. [CrossRef] [PubMed]

84. Batbayal, T.; Ishii, Y.; Nomura, Y.; Watanabe, M.; Yasuko, T.; Nakamura, S. Change in decorin during aging of rat placenta. Connect. Tissue Res. 2006, 47, 235-241. [CrossRef] [PubMed]

85. Li, Y.; Liu, Y.; Xia, W.; Lei, D.; Voorhees, J.J.; Fisher, G.J. Age-dependent alterations of decorin glycosaminoglycans in human skin. Sci. Rep. 2013, 3, 2422. [CrossRef] [PubMed]

86. Dunkman, A.A.; Buckley, M.R.; Mienaltowski, M.J.; Adams, S.M.; Thomas, S.J.; Satchell, L.; Kumar, A.; Pathmanathan, L.; Beason, D.P.; Iozzo, R.V.; et al. Decorin expression is important for age-related changes in tendon structure and mechanical properties. Matrix Biol. 2013, 32, 3-13. [CrossRef]

87. Dunkman, A.A.; Buckley, M.R.; Mienaltowski, M.J.; Adams, S.M.; Thomas, S.J.; Kumar, A.; Beason, D.P.; Iozzo, R.V.; Birk, D.E.; Soslowsky, L.J. The injury response of aged tendons in the absence of biglycan and decorin. Matrix Biol. 2014, 35, 232-238. [CrossRef]

88. Visser, N.A.; de Koning, M.H.; Lammi, M.J.; Hakkinen, T.; Tammi, M.; van Kampen, G.P. Increase of decorin content in articular cartilage following running. Connect. Tissue Res. 1998, 37, 295-302. [CrossRef]

89. Heinemeier, K.M.; Bjerrum, S.S.; Schjerling, P.; Kjaer, M. Expression of extracellular matrix components and related growth factors in human tendon and muscle after acute exercise. Scand. J. Med. Sci. Sports 2013, 23, e150-e161. [CrossRef]

90. Xu, S.Y.; Liu, S.Y.; Xu, L.; Deng, S.Y.; He, Y.B.; Li, S.F.; Ni, G.X. Response of decorin to different intensity treadmill running. Mol. Med. Rep. 2018, 17, 7911-7917. [CrossRef]

91. Salmon, W.D., Jr.; Daughaday, W.H. A hormonally controlled serum factor which stimulates sulfate incorporation by cartilage in vitro. J. Lab. Clin. Med. 1957, 49, 825-836.

92. Rinderknecht, E.; Humbel, R.E. The amino acid sequence of human insulin-like growth factor I and its structural homology with proinsulin. J. Biol. Chem. 1978, 253, 2769-2776.

93. Jansen, M.; van Schaik, F.M.; Ricker, A.T.; Bullock, B.; Woods, D.E.; Gabbay, K.H.; Nussbaum, A.L.; Sussenbach, J.S.; Van den Brande, J.L. Sequence of cDNA encoding human insulin-like growth factor I precursor. Nature 1983, 306, 609-611. [CrossRef] [PubMed]

94. Hoppener, J.W.; de Pagter-Holthuizen, P.; Geurts van Kessel, A.H.; Jansen, M.; Kittur, S.D.; Antonarakis, S.E.; Lips, C.J.; Sussenbach, J.S. The human gene encoding insulin-like growth factor I is located on chromosome 12. Hum. Genet. 1985, 69, 157-160. [CrossRef] [PubMed]

95. Neirijnck, Y.; Papaioannou, M.D.; Nef, S. The insulin/IGF system in mammalian sexual development and reproduction. Int. J. Mol. Sci. 2019, 20, 4440. [CrossRef] [PubMed]

96. Pedersen, B.K.; Febbraio, M.A. Muscles, exercise and obesity: Skeletal muscle as a secretory organ. Nat. Rev. Endocrinol. 2012, 8, 457-465. [CrossRef]

97. Bando, H.; Zhang, C.; Takada, Y.; Yamasaki, R.; Saito, S. Impaired secretion of growth hormone-releasing hormone, growth hormone and IGF-I in elderly men. Acta Endocrinol. 1991, 124, 31-36. [CrossRef] [PubMed]

98. Yamamoto, H.; Sohmiya, M.; Oka, N.; Kato, Y. Effects of aging and sex on plasma insulin-like growth factor I (IGF-I) levels in normal adults. Acta Endocrinol. 1991, 124, 497-500. [CrossRef]

99. Ceda, G.P.; Dall'Aglio, E.; Magnacavallo, A.; Vargas, N.; Fontana, V.; Maggio, M.; Valenti, G.; Lee, P.D.; Hintz, R.L.; Hoffman, A.R. The insulin-like growth factor axis and plasma lipid levels in the elderly. J. Clin. Endocrinol. Metab. 1998, 83, 499-502. [CrossRef]

100. Krishnaraj, R.; Zaks, A.; Unterman, T. Relationship between plasma IGF-I levels, in vitro correlates of immunity, and human senescence. Clin. Immunol. Immunopathol. 1998, 88, 264-270. [CrossRef]

101. Kucera, R.; Topolcan, O.; Pecen, L.; Kinkorova, J.; Svobodova, S.; Windrichova, J.; Fuchsova, R. Reference values of IGF1, IGFBP3 and IGF1/IGFBP3 ratio in adult population in the Czech Republic. Clin. Chim. Acta 2015, 444, 271-277. [CrossRef]

102. Sell, C.; Ptasznik, A.; Chang, C.D.; Swantek, J.; Cristofalo, V.J.; Baserga, R. IGF-1 receptor levels and the proliferation of young and senescent human fibroblasts. Biochem. Biophys. Res. Commun. 1993, 194, 259-265. [CrossRef] 
103. Kveiborg, M.; Flyvbjerg, A.; Rattan, S.I.; Kassem, M. Changes in the insulin-like growth factor-system may contribute to in vitro age-related impaired osteoblast functions. Exp. Gerontol. 2000, 35, 1061-1074. [CrossRef]

104. Gong, Z.; Kennedy, O.; Sun, H.; Wu, Y.; Williams, G.A.; Klein, L.; Cardoso, L.; Matheny, R.W., Jr.; Hubbard, G.B.; Ikeno, Y.; et al. Reductions in serum IGF-1 during aging impair health span. Aging Cell 2014, 13, 408-418. [CrossRef] [PubMed]

105. Pharaoh, G.; Owen, D.; Yeganeh, A.; Premkumar, P.; Farley, J.; Bhaskaran, S.; Ashpole, N.; Kinter, M.; Van Remmen, H.; Logan, S. Disparate central and peripheral effects of circulating IGF-1 deficiency on tissue mitochondrial function. Mol. Neurobiol. 2020, 57, 1317-1331. [CrossRef] [PubMed]

106. Tay, L.; Ding, Y.Y.; Leung, B.P.; Ismail, N.H.; Yeo, A.; Yew, S.; Tay, K.S.; Tan, C.H.; Chong, M.S. Sex-specific differences in risk factors for sarcopenia amongst community-dwelling older adults. Age 2015, 37, 121. [CrossRef] [PubMed]

107. Chew, J.; Tay, L.; Lim, J.P.; Leung, B.P.; Yeo, A.; Yew, S.; Ding, Y.Y.; Lim, W.S. Serum myostatin and IGF-1 as gender-specific biomarkers of frailty and low muscle mass in community-dwelling older adults. J. Nutr. Health Aging 2019, 23, 979-986. [CrossRef] [PubMed]

108. Deuschle, M.; Blum, W.F.; Frystyk, J.; Orskov, H.; Schweiger, U.; Weber, B.; Korner, A.; Gotthardt, U.; Schmider, J.; Standhardt, H.; et al. Endurance training and its effect upon the activity of the GH-IGFs system in the elderly. Int. J. Sports Med. 1998, 19, 250-254. [CrossRef]

109. Singh, M.A.; Ding, W.; Manfredi, T.J.; Solares, G.S.; O’Neill, E.F.; Clements, K.M.; Ryan, N.D.; Kehayias, J.J.; Fielding, R.A.; Evans, W.J. Insulin-like growth factor I in skeletal muscle after weight-lifting exercise in frail elders. Am. J. Physiol. 1999, 277, E135-E143. [CrossRef]

110. Liu, M.; Stevens-Lapsley, J.E.; Jayaraman, A.; Ye, F.; Conover, C.; Walter, G.A.; Bose, P.; Thompson, F.J.; Borst, S.E.; Vandenborne, K. Impact of treadmill locomotor training on skeletal muscle IGF1 and myogenic regulatory factors in spinal cord injured rats. Eur. J. Appl. Physiol. 2010, 109, 709-720. [CrossRef]

111. Dieli-Conwright, C.M.; Kiwata, J.L.; Tuzon, C.T.; Spektor, T.M.; Sattler, F.R.; Rice, J.C.; Schroeder, E.T. Acute response of PGC-1alpha and IGF-1 isoforms to maximal eccentric exercise in skeletal muscle of postmenopausal women. J. Strength Cond. Res. 2016, 30, 1161-1170. [CrossRef]

112. Burton, J.D.; Bamford, R.N.; Peters, C.; Grant, A.J.; Kurys, G.; Goldman, C.K.; Brennan, J.; Roessler, E.; Waldmann, T.A. A lymphokine, provisionally designated interleukin $\mathrm{T}$ and produced by a human adult T-cell leukemia line, stimulates T-cell proliferation and the induction of lymphokine-activated killer cells. Proc. Natl. Acad. Sci. USA 1994, 91, 4935-4939. [CrossRef]

113. Grabstein, K.H.; Eisenman, J.; Shanebeck, K.; Rauch, C.; Srinivasan, S.; Fung, V.; Beers, C.; Richardson, J.; Schoenborn, M.A.; Ahdieh, M.; et al. Cloning of a T cell growth factor that interacts with the beta chain of the interleukin-2 receptor. Science 1994, 264, 965-968. [CrossRef] [PubMed]

114. Steel, J.C.; Waldmann, T.A.; Morris, J.C. Interleukin-15 biology and its therapeutic implications in cancer. Trends Pharmacol. Sci. 2012, 33, 35-41. [CrossRef] [PubMed]

115. Quinn, L.S.; Anderson, B.G. Interleukin-15, IL-15 receptor-alpha, and obesity: Concordance of laboratory animal and human genetic studies. J. Obes. 2011, 2011, 456347. [CrossRef]

116. Klebanoff, C.A.; Finkelstein, S.E.; Surman, D.R.; Lichtman, M.K.; Gattinoni, L.; Theoret, M.R.; Grewal, N.; Spiess, P.J.; Antony, P.A.; Palmer, D.C.; et al. IL-15 enhances the in vivo antitumor activity of tumor-reactive CD8+ T cells. Proc. Natl. Acad. Sci. USA 2004, 101, 1969-1974. [CrossRef] [PubMed]

117. Malamut, G.; El Machhour, R.; Montcuquet, N.; Martin-Lanneree, S.; Dusanter-Fourt, I.; Verkarre, V.; Mention, J.J.; Rahmi, G.; Kiyono, H.; Butz, E.A.; et al. IL-15 triggers an antiapoptotic pathway in human intraepithelial lymphocytes that is a potential new target in celiac disease-associated inflammation and lymphomagenesis. J. Clin. Investig. 2010, 120, 2131-2143. [CrossRef]

118. Wu, J. IL-15 agonists: The cancer cure cytokine. J. Mol. Genet. Med. 2013, 7, 85. [CrossRef]

119. Brandt, C.; Pedersen, B.K. The role of exercise-induced myokines in muscle homeostasis and the defense against chronic diseases. J. Biomed. Biotechnol. 2010, 2010, 520258. [CrossRef]

120. Marzetti, E.; Carter, C.S.; Wohlgemuth, S.E.; Lees, H.A.; Giovannini, S.; Anderson, B.; Quinn, L.S.; Leeuwenburgh, C. Changes in IL-15 expression and death-receptor apoptotic signaling in rat gastrocnemius muscle with aging and life-long calorie restriction. Mech. Ageing Dev. 2009, 130, 272-280. [CrossRef] 
121. Quinn, L.S.; Anderson, B.G.; Strait-Bodey, L.; Wolden-Hanson, T. Serum and muscle interleukin-15 levels decrease in aging mice: Correlation with declines in soluble interleukin-15 receptor alpha expression. Exp. Gerontol. 2010, 45, 106-112. [CrossRef]

122. Crane, J.D.; MacNeil, L.G.; Lally, J.S.; Ford, R.J.; Bujak, A.L.; Brar, I.K.; Kemp, B.E.; Raha, S.; Steinberg, G.R.; Tarnopolsky, M.A. Exercise-stimulated interleukin-15 is controlled by AMPK and regulates skin metabolism and aging. Aging Cell 2015, 14, 625-634. [CrossRef]

123. Yalcin, A.; Silay, K.; Balik, A.R.; Avcioglu, G.; Aydin, A.S. The relationship between plasma interleukin-15 levels and sarcopenia in outpatient older people. Aging Clin. Exp. Res. 2018, 30, 783-790. [CrossRef]

124. Nelke, C.; Dziewas, R.; Minnerup, J.; Meuth, S.G.; Ruck, T. Skeletal muscle as potential central link between sarcopenia and immune senescence. EBioMedicine 2019, 49, 381-388. [CrossRef] [PubMed]

125. Cui, G.; Hara, T.; Simmons, S.; Wagatsuma, K.; Abe, A.; Miyachi, H.; Kitano, S.; Ishii, M.; Tani-ichi, S.; Ikuta, K. Characterization of the IL-15 niche in primary and secondary lymphoid organs in vivo. Proc. Natl. Acad. Sci. USA 2014, 111, 1915-1920. [CrossRef]

126. Riechman, S.E.; Balasekaran, G.; Roth, S.M.; Ferrell, R.E. Association of interleukin-15 protein and interleukin-15 receptor genetic variation with resistance exercise training responses. J. Appl. Physiol. 2004, 97, 2214-2219. [CrossRef] [PubMed]

127. Perez-Lopez, A.; McKendry, J.; Martin-Rincon, M.; Morales-Alamo, D.; Perez-Kohler, B.; Valades, D.; Bujan, J.; Calbet, J.A.L.; Breen, L. Skeletal muscle IL-15/IL-15Ralpha and myofibrillar protein synthesis after resistance exercise. Scand. J. Med. Sci. Sports 2018, 28, 116-125. [CrossRef]

128. Kim, H.J.; Park, J.Y.; Oh, S.L.; Kim, Y.A.; So, B.; Seong, J.K.; Song, W. Effect of treadmill exercise on interleukin-15 expression and glucose tolerance in zucker diabetic fatty rats. Diabetes Metab. J. 2013, 37, 358-364. [CrossRef] [PubMed]

129. Rinnov, A.; Yfanti, C.; Nielsen, S.; Akerstrom, T.C.; Peijs, L.; Zankari, A.; Fischer, C.P.; Pedersen, B.K. Endurance training enhances skeletal muscle interleukin-15 in human male subjects. Endocrine 2014, 45, 271-278. [CrossRef] [PubMed]

130. Hingorjo, M.R.; Zehra, S.; Saleem, S.; Qureshi, M.A. Serum Interleukin-15 and its relationship with adiposity Indices before and after short-term endurance exercise. Pak. J. Med. Sci. 2018, 34, 1125-1131. [CrossRef] [PubMed]

131. Yargic, M.P.; Torgutalp, S.; Akin, S.; Babayeva, N.; Torgutalp, M.; Demirel, H.A. Acute long-distance trail running increases serum IL-6, IL-15, and Hsp72 levels. Appl. Physiol. Nutr. Metab. 2019, 44, 627-631. [CrossRef]

132. Brown, J.A.; Sherrod, S.D.; Goodwin, C.R.; Brewer, B.; Yang, L.; Garbett, K.A.; Li, D.; McLean, J.A.; Wikswo, J.P.; Mirnics, K. Metabolic consequences of interleukin-6 challenge in developing neurons and astroglia. J. Neuroinflamm. 2014, 11, 183. [CrossRef] [PubMed]

133. Kouda, K.; Furusawa, K.; Sugiyama, H.; Sumiya, T.; Ito, T.; Tajima, F.; Shimizu, K. Does 20-min arm crank ergometer exercise increase plasma interleukin-6 in individuals with cervical spinal cord injury? Eur. J. Appl. Physiol. 2012, 112, 597-604. [CrossRef] [PubMed]

134. Zilberstein, A.; Ruggieri, R.; Korn, J.H.; Revel, M. Structure and expression of cDNA and genes for human interferon-beta-2, a distinct species inducible by growth-stimulatory cytokines. EMBO J. 1986, 5, 2529-2537. [CrossRef] [PubMed]

135. Hirano, T.; Yasukawa, K.; Harada, H.; Taga, T.; Watanabe, Y.; Matsuda, T.; Kashiwamura, S.; Nakajima, K.; Koyama, K.; Iwamatsu, A.; et al. Complementary DNA for a novel human interleukin (BSF-2) that induces B lymphocytes to produce immunoglobulin. Nature 1986, 324, 73-76. [CrossRef] [PubMed]

136. Sutherland, G.R.; Baker, E.; Callen, D.F.; Hyland, V.J.; Wong, G.; Clark, S.; Jones, S.S.; Eglinton, L.K.; Shannon, M.F.; Lopez, A.F.; et al. Interleukin 4 is at $5 q 31$ and interleukin 6 is at 7p15. Hum. Genet. 1988, 79, 335-337. [CrossRef]

137. Yamasaki, K.; Taga, T.; Hirata, Y.; Yawata, H.; Kawanishi, Y.; Seed, B.; Taniguchi, T.; Hirano, T.; Kishimoto, T. Cloning and expression of the human interleukin-6 (BSF-2/IFN beta 2) receptor. Science 1988, 241, 825-828. [CrossRef]

138. Hibi, M.; Murakami, M.; Saito, M.; Hirano, T.; Taga, T.; Kishimoto, T. Molecular cloning and expression of an IL-6 signal transducer, gp130. Cell 1990, 63, 1149-1157. [CrossRef]

139. Wei, J.; Xu, H.; Davies, J.L.; Hemmings, G.P. Increase of plasma IL-6 concentration with age in healthy subjects. Life Sci. 1992, 51, 1953-1956. [CrossRef] 
140. Ershler, W.B.; Sun, W.H.; Binkley, N.; Gravenstein, S.; Volk, M.J.; Kamoske, G.; Klopp, R.G.; Roecker, E.B.; Daynes, R.A.; Weindruch, R. Interleukin-6 and aging: Blood levels and mononuclear cell production increase with advancing age and in vitro production is modifiable by dietary restriction. Lymphokine Cytokine Res. 1993, 12, 225-230. [PubMed]

141. Hager, K.; Machein, U.; Krieger, S.; Platt, D.; Seefried, G.; Bauer, J. Interleukin-6 and selected plasma proteins in healthy persons of different ages. Neurobiol. Aging 1994, 15, 771-772. [CrossRef]

142. Kania, D.M.; Binkley, N.; Checovich, M.; Havighurst, T.; Schilling, M.; Ershler, W.B. Elevated plasma levels of interleukin-6 in postmenopausal women do not correlate with bone density. J. Am. Geriatr. Soc. 1995, 43, 236-239. [CrossRef]

143. Harris, T.B.; Ferrucci, L.; Tracy, R.P.; Corti, M.C.; Wacholder, S.; Ettinger, W.H., Jr.; Heimovitz, H.; Cohen, H.J.; Wallace, R. Associations of elevated interleukin-6 and C-reactive protein levels with mortality in the elderly. Am. J. Med. 1999, 106, 506-512. [CrossRef]

144. Forcina, L.; Miano, C.; Scicchitano, B.M.; Rizzuto, E.; Berardinelli, M.G.; De Benedetti, F.; Pelosi, L.; Musaro, A. Increased circulating levels of interleukin- 6 affect the redox balance in skeletal muscle. Oxid. Med. Cell. Longev. 2019, 2019, 3018584. [CrossRef] [PubMed]

145. Serrano, A.L.; Baeza-Raja, B.; Perdiguero, E.; Jardi, M.; Munoz-Canoves, P. Interleukin-6 is an essential regulator of satellite cell-mediated skeletal muscle hypertrophy. Cell Metab. 2008, 7, 33-44. [CrossRef] [PubMed]

146. Abid, H.; Hart, C.; Lanza, I. 3540 effects of local interleukin-6 on mitochondrial physiology in skeletal muscle. J. Clin. Transl. Sci. 2019, 3, 10. [CrossRef]

147. Sprenger, H.; Jacobs, C.; Nain, M.; Gressner, A.M.; Prinz, H.; Wesemann, W.; Gemsa, D. Enhanced release of cytokines, interleukin-2 receptors, and neopterin after long-distance running. Clin. Immunol. Immunopathol. 1992, 63, 188-195. [CrossRef]

148. Covington, J.D.; Tam, C.S.; Bajpeyi, S.; Galgani, J.E.; Noland, R.C.; Smith, S.R.; Redman, L.M.; Ravussin, E. Myokine expression in muscle and myotubes in response to exercise stimulation. Med. Sci. Sports Exerc. 2016, 48, 384-390. [CrossRef]

149. Briken, S.; Rosenkranz, S.C.; Keminer, O.; Patra, S.; Ketels, G.; Heesen, C.; Hellweg, R.; Pless, O.; Schulz, K.H.; Gold, S.M. Effects of exercise on Irisin, BDNF and IL-6 serum levels in patients with progressive multiple sclerosis. J. Neuroimmunol. 2016, 299, 53-58. [CrossRef]

150. Cornish, S.M.; Chase, J.E.; Bugera, E.M.; Giesbrecht, G.G. Systemic IL-6 and myoglobin response to three different resistance exercise intensities in older men. J. Aging Phys. Act. 2018, 26, 451-456. [CrossRef]

151. Bugera, E.M.; Duhamel, T.A.; Peeler, J.D.; Cornish, S.M. The systemic myokine response of decorin, interleukin-6 (IL-6) and interleukin-15 (IL-15) to an acute bout of blood flow restricted exercise. Eur. J. Appl. Physiol. 2018, 118, 2679-2686. [CrossRef] [PubMed]

152. Eaton, M.; Granata, C.; Barry, J.; Safdar, A.; Bishop, D.; Little, J.P. Impact of a single bout of high-intensity interval exercise and short-term interval training on interleukin-6, FNDC5, and METRNL mRNA expression in human skeletal muscle. J. Sport Health Sci. 2018, 7, 191-196. [CrossRef]

153. Paulson, T.A.; Goosey-Tolfrey, V.L.; Lenton, J.P.; Leicht, C.A.; Bishop, N.C. Spinal cord injury level and the circulating cytokine response to strenuous exercise. Med. Sci. Sports Exerc. 2013, 45, 1649-1655. [CrossRef] [PubMed]

154. Ogawa, T.; Nakamura, T.; Banno, M.; Sasaki, Y.; Umemoto, Y.; Kouda, K.; Kawasaki, T.; Tajima, F. Elevation of interleukin- 6 and attenuation of tumor necrosis factor-alpha during wheelchair half marathon in athletes with cervical spinal cord injuries. Spinal Cord 2014, 52, 601-605. [CrossRef]

155. Bobbo, V.C.D.; Jara, C.P.; Mendes, N.F.; Morari, J.; Velloso, L.A.; Araujo, E.P. Interleukin-6 expression by hypothalamic microglia in multiple inflammatory contexts: A systematic review. Biomed. Res. Int. 2019, 2019, 1365210. [CrossRef] [PubMed]

156. Hojman, P.; Brolin, C.; Norgaard-Christensen, N.; Dethlefsen, C.; Lauenborg, B.; Olsen, C.K.; Abom, M.M.; Krag, T.; Gehl, J.; Pedersen, B.K. IL-6 release from muscles during exercise is stimulated by lactate-dependent protease activity. Am. J. Physiol. Endocrinol. Metab. 2019, 316, E940-E947. [CrossRef]

157. Garneau, L.; Parsons, S.A.; Smith, S.R.; Mulvihill, E.E.; Sparks, L.M.; Aguer, C. Plasma myokine concentrations after acute exercise in non-obese and obese sedentary women. Front. Physiol. 2020, 11, 18. [CrossRef] [PubMed] 
158. Pedersen, B.K.; Fischer, C.P. Beneficial health effects of exercise-the role of IL-6 as a myokine. Trends Pharmacol. Sci. 2007, 28, 152-156. [CrossRef]

159. Ellingsgaard, H.; Hojman, P.; Pedersen, B.K. Exercise and health-Emerging roles of IL-6. Curr. Opin. Physiol. 2019, 10, 49-54. [CrossRef]

160. Teufel, A.; Malik, N.; Mukhopadhyay, M.; Westphal, H. Frcp1 and Frcp2, two novel fibronectin type III repeat containing genes. Gene 2002, 297, 79-83. [CrossRef]

161. Staiger, H.; Bohm, A.; Scheler, M.; Berti, L.; Machann, J.; Schick, F.; Machicao, F.; Fritsche, A.; Stefan, N.; Weigert, C.; et al. Common genetic variation in the human FNDC5 locus, encoding the novel muscle-derived 'browning' factor irisin, determines insulin sensitivity. PLoS ONE 2013, 8, e61903. [CrossRef]

162. Novelle, M.G.; Contreras, C.; Romero-Pico, A.; Lopez, M.; Dieguez, C. Irisin, two years later. Int. J. Endocrinol. 2013, 2013, 746281. [CrossRef]

163. Sanchis-Gomar, F.; Perez-Quilis, C. The p38-PGC-1alpha-irisin-betatrophin axis: Exploring new pathways in insulin resistance. Adipocyte 2014, 3, 67-68. [CrossRef] [PubMed]

164. Huh, J.Y.; Mougios, V.; Kabasakalis, A.; Fatouros, I.; Siopi, A.; Douroudos, I.I.; Filippaios, A.; Panagiotou, G.; Park, K.H.; Mantzoros, C.S. Exercise-induced irisin secretion is independent of age or fitness level and increased irisin may directly modulate muscle metabolism through AMPK activation. J. Clin. Endocrinol. Metab. 2014, 99, E2154-E2161. [CrossRef] [PubMed]

165. Chang, J.S.; Kim, T.H.; Nguyen, T.T.; Park, K.S.; Kim, N.; Kong, I.D. Circulating irisin levels as a predictive biomarker for sarcopenia: A cross-sectional community-based study. Geriatr. Gerontol. Int. 2017, 17, 2266-2273. [CrossRef] [PubMed]

166. Bi, J.; Yang, L.; Wang, T.; Zhang, J.; Li, T.; Ren, Y.; Wang, M.; Chen, X.; Lv, Y.; Wu, R. Irisin improves autophagy of aged hepatocytes via increasing telomerase activity in liver injury. Oxid. Med. Cell. Longev. 2020, 2020, 6946037. [CrossRef] [PubMed]

167. Ruan, Q.; Huang, Y.; Yang, L.; Ruan, J.; Gu, W.; Zhang, X.; Zhang, Y.; Zhang, W.; Yu, Z. The effects of both age and sex on irisin levels in paired plasma and cerebrospinal fluid in healthy humans. Peptides 2019, 113, 41-51. [CrossRef]

168. Rana, K.S.; Arif, M.; Hill, E.J.; Aldred, S.; Nagel, D.A.; Nevill, A.; Randeva, H.S.; Bailey, C.J.; Bellary, S.; Brown, J.E. Plasma irisin levels predict telomere length in healthy adults. Age 2014, 36, 995-1001. [CrossRef]

169. Huh, J.Y.; Panagiotou, G.; Mougios, V.; Brinkoetter, M.; Vamvini, M.T.; Schneider, B.E.; Mantzoros, C.S. FNDC5 and irisin in humans: I. predictors of circulating concentrations in serum and plasma and II. mRNA expression and circulating concentrations in response to weight loss and exercise. Metabolism 2012, 61, 1725-1738. [CrossRef]

170. Lecker, S.H.; Zavin, A.; Cao, P.; Arena, R.; Allsup, K.; Daniels, K.M.; Joseph, J.; Schulze, P.C.; Forman, D.E. Expression of the irisin precursor FNDC5 in skeletal muscle correlates with aerobic exercise performance in patients with heart failure. Circ. Heart Fail. 2012, 5, 812-818. [CrossRef]

171. Brenmoehl, J.; Albrecht, E.; Komolka, K.; Schering, L.; Langhammer, M.; Hoeflich, A.; Maak, S. Irisin is elevated in skeletal muscle and serum of mice immediately after acute exercise. Int. J. Biol. Sci. 2014, 10, 338-349. [CrossRef]

172. Kurdiova, T.; Balaz, M.; Vician, M.; Maderova, D.; Vlcek, M.; Valkovic, L.; Srbecky, M.; Imrich, R.; Kyselovicova, O.; Belan, V.; et al. Effects of obesity, diabetes and exercise on Fndc5 gene expression and irisin release in human skeletal muscle and adipose tissue: In vivo and in vitro studies. J. Physiol. 2014, 592, 1091-1107. [CrossRef]

173. Tsuchiya, Y.; Mizuno, S.; Goto, K. Irisin response to downhill running exercise in humans. J. Exerc. Nutr. Biochem. 2018, 22, 12-17. [CrossRef] [PubMed]

174. Pang, M.; Yang, J.; Rao, J.; Wang, H.; Zhang, J.; Wang, S.; Chen, X.; Dong, X. Time-dependent changes in increased levels of plasma irisin and muscle PGC-1alpha and FNDC5 after exercise in mice. Tohoku J. Exp. Med. 2018, 244, 93-103. [CrossRef] [PubMed]

175. Kang, Y.S.; Kim, J.C.; Kim, J.S.; Kim, S.H. Effects of swimming exercise on serum irisin and bone FNDC5 in rat models of high-fat diet-induced osteoporosis. J. Sports Sci. Med. 2019, 18, 596-603. [PubMed]

176. Maalouf, G.E.; El Khoury, D. Exercise-induced irisin, the fat browning myokine, as a potential anticancer agent. J. Obes. 2019, 2019, 6561726. [CrossRef] 
177. Kim, H.J.; So, B.; Choi, M.; Kang, D.; Song, W. Resistance exercise training increases the expression of irisin concomitant with improvement of muscle function in aging mice and humans. Exp. Gerontol. 2015, 70, 11-17. [CrossRef]

178. Aydin, S.; Kuloglu, T.; Aydin, S.; Eren, M.N.; Celik, A.; Yilmaz, M.; Kalayci, M.; Sahin, I.; Gungor, O.; Gurel, A.; et al. Cardiac, skeletal muscle and serum irisin responses to with or without water exercise in young and old male rats: Cardiac muscle produces more irisin than skeletal muscle. Peptides 2014, 52, 68-73. [CrossRef]

179. Bubak, M.P.; Heesch, M.W.S.; Shute, R.J.; Dinan, N.E.; Laursen, T.L.; DT, L.A.S.; Slivka, D.R. Irisin and fibronectin type III domain-containing 5 responses to exercise in different environmental conditions. Int. J. Exerc. Sci. 2017, 10, 666-680.

180. Fox, J.; Rioux, B.V.; Goulet, E.D.B.; Johanssen, N.M.; Swift, D.L.; Bouchard, D.R.; Loewen, H.; Senechal, M. Effect of an acute exercise bout on immediate post-exercise irisin concentration in adults: A meta-analysis. Scand. J. Med. Sci. Sports 2018, 28, 16-28. [CrossRef]

181. Zhou, X.; Xu, M.; Bryant, J.L.; Ma, J.; Xu, X. Exercise-induced myokine FNDC5/irisin functions in cardiovascular protection and intracerebral retrieval of synaptic plasticity. Cell Biosci. 2019, 9, 32. [CrossRef]

182. Lourenco, M.V.; Frozza, R.L.; de Freitas, G.B.; Zhang, H.; Kincheski, G.C.; Ribeiro, F.C.; Goncalves, R.A.; Clarke, J.R.; Beckman, D.; Staniszewski, A.; et al. Exercise-linked FNDC5/irisin rescues synaptic plasticity and memory defects in Alzheimer's models. Nat. Med. 2019, 25, 165-175. [CrossRef]

183. Ma, E.B.; Sahar, N.E.; Jeong, M.; Huh, J.Y. Irisin exerts inhibitory effect on adipogenesis through regulation of Wnt signaling. Front. Physiol. 2019, 10, 1085. [CrossRef] [PubMed]

184. McPherron, A.C.; Lawler, A.M.; Lee, S.J. Regulation of skeletal muscle mass in mice by a new TGF-beta superfamily member. Nature 1997, 387, 83-90. [CrossRef] [PubMed]

185. Sharma, M.; Kambadur, R.; Matthews, K.G.; Somers, W.G.; Devlin, G.P.; Conaglen, J.V.; Fowke, P.J.; Bass, J.J. Myostatin, a transforming growth factor-beta superfamily member, is expressed in heart muscle and is upregulated in cardiomyocytes after infarct. J. Cell. Physiol. 1999, 180, 1-9. [CrossRef]

186. Lee, S.J.; Lee, Y.S.; Zimmers, T.A.; Soleimani, A.; Matzuk, M.M.; Tsuchida, K.; Cohn, R.D.; Barton, E.R. Regulation of muscle mass by follistatin and activins. Mol. Endocrinol. 2010, 24, 1998-2008. [CrossRef] [PubMed]

187. Gonzalez-Cadavid, N.F.; Taylor, W.E.; Yarasheski, K.; Sinha-Hikim, I.; Ma, K.; Ezzat, S.; Shen, R.; Lalani, R.; Asa, S.; Mamita, M.; et al. Organization of the human myostatin gene and expression in healthy men and HIV-infected men with muscle wasting. Proc. Natl. Acad. Sci. USA 1998, 95, 14938-14943. [CrossRef] [PubMed]

188. Yarasheski, K.E.; Bhasin, S.; Sinha-Hikim, I.; Pak-Loduca, J.; Gonzalez-Cadavid, N.F. Serum myostatin-immunoreactive protein is increased in 60-92 year old women and men with muscle wasting. J. Nutr. Health Aging 2002, 6, 343-348. [PubMed]

189. Walker, K.S.; Kambadur, R.; Sharma, M.; Smith, H.K. Resistance training alters plasma myostatin but not IGF-1 in healthy men. Med. Sci. Sports Exerc. 2004, 36, 787-793. [CrossRef]

190. MacKenzie, M.G.; Hamilton, D.L.; Pepin, M.; Patton, A.; Baar, K. Inhibition of myostatin signaling through notch activation following acute resistance exercise. PLoS ONE 2013, 8, e68743. [CrossRef]

191. Matsakas, A.; Friedel, A.; Hertrampf, T.; Diel, P. Short-term endurance training results in a muscle-specific decrease of myostatin mRNA content in the rat. Acta Physiol. Scand. 2005, 183, 299-307. [CrossRef]

192. Ko, I.G.; Jeong, J.W.; Kim, Y.H.; Jee, Y.S.; Kim, S.E.; Kim, S.H.; Jin, J.J.; Kim, C.J.; Chung, K.J. Aerobic exercise affects myostatin expression in aged rat skeletal muscles: A possibility of antiaging effects of aerobic exercise related with pelvic floor muscle and urethral rhabdosphincter. Int. Neurourol. J. 2014, 18, 77-85. [CrossRef]

193. Hittel, D.S.; Axelson, M.; Sarna, N.; Shearer, J.; Huffman, K.M.; Kraus, W.E. Myostatin decreases with aerobic exercise and associates with insulin resistance. Med. Sci. Sports Exerc. 2010, 42, 2023-2029. [CrossRef] [PubMed]

194. Ryan, A.S.; Li, G.; Blumenthal, J.B.; Ortmeyer, H.K. Aerobic exercise + weight loss decreases skeletal muscle myostatin expression and improves insulin sensitivity in older adults. Obesity 2013, 21, 1350-1356. [CrossRef] [PubMed]

195. Lenk, K.; Schur, R.; Linke, A.; Erbs, S.; Matsumoto, Y.; Adams, V.; Schuler, G. Impact of exercise training on myostatin expression in the myocardium and skeletal muscle in a chronic heart failure model. Eur. J. Heart Fail. 2009, 11, 342-348. [CrossRef] [PubMed] 
196. Lenk, K.; Erbs, S.; Hollriegel, R.; Beck, E.; Linke, A.; Gielen, S.; Winkler, S.M.; Sandri, M.; Hambrecht, R.; Schuler, G.; et al. Exercise training leads to a reduction of elevated myostatin levels in patients with chronic heart failure. Eur. J. Prev. Cardiol. 2012, 19, 404-411. [CrossRef]

197. Zhang, L.; Rajan, V.; Lin, E.; Hu, Z.; Han, H.Q.; Zhou, X.; Song, Y.; Min, H.; Wang, X.; Du, J.; et al. Pharmacological inhibition of myostatin suppresses systemic inflammation and muscle atrophy in mice with chronic kidney disease. FASEB J. 2011, 25, 1653-1663. [CrossRef]

198. Zhou, Y.; Hellberg, M.; Hellmark, T.; Hoglund, P.; Clyne, N. Muscle mass and plasma myostatin after exercise training: A substudy of Renal Exercise (RENEXC)-a randomized controlled trial. Nephrol. Dial. Transplant. 2019. [CrossRef]

199. Baati, N.; Feillet-Coudray, C.; Fouret, G.; Vernus, B.; Goustard, B.; Jollet, M.; Bertrand-Gaday, C.; Coudray, C.; Lecomte, J.; Bonnieu, A.; et al. New evidence of exercise training benefits in myostatin-deficient mice: Effect on lipidomic abnormalities. Biochem. Biophys. Res. Commun. 2019, 516, 89-95. [CrossRef]

200. Welle, S.; Bhatt, K.; Shah, B.; Thornton, C. Insulin-like growth factor-1 and myostatin mRNA expression in muscle: Comparison between 62-77 and 21-31 yr old men. Exp. Gerontol. 2002, 37, 833-839. [CrossRef]

201. Baumann, A.P.; Ibebunjo, C.; Grasser, W.A.; Paralkar, V.M. Myostatin expression in age and denervation-induced skeletal muscle atrophy. J. Musculoskelet. Neuronal Interact. 2003, 3, 8-16.

202. Schafer, M.J.; Atkinson, E.J.; Vanderboom, P.M.; Kotajarvi, B.; White, T.A.; Moore, M.M.; Bruce, C.J.; Greason, K.L.; Suri, R.M.; Khosla, S.; et al. Quantification of GDF11 and myostatin in human aging and cardiovascular disease. Cell Metab. 2016, 23, 1207-1215. [CrossRef]

203. Peng, L.N.; Lee, W.J.; Liu, L.K.; Lin, M.H.; Chen, L.K. Healthy community-living older men differ from women in associations between myostatin levels and skeletal muscle mass. J. Cachexia Sarcopenia Muscle 2018, 9, 635-642. [CrossRef] [PubMed]

204. Hunger, C.; Odemis, V.; Engele, J. Expression and function of the SDF-1 chemokine receptors CXCR4 and CXCR7 during mouse limb muscle development and regeneration. Exp. Cell Res. 2012, 318, 2178-2190. [CrossRef] [PubMed]

205. Tashiro, K.; Tada, H.; Heilker, R.; Shirozu, M.; Nakano, T.; Honjo, T. Signal sequence trap: A cloning strategy for secreted proteins and type I membrane proteins. Science 1993, 261, 600-603. [CrossRef] [PubMed]

206. Bleul, C.C.; Farzan, M.; Choe, H.; Parolin, C.; Clark-Lewis, I.; Sodroski, J.; Springer, T.A. The lymphocyte chemoattractant SDF-1 is a ligand for LESTR/fusin and blocks HIV-1 entry. Nature 1996, 382, 829-833. [CrossRef]

207. Adlere, I.; Caspar, B.; Arimont, M.; Dekkers, S.; Visser, K.; Stuijt, J.; de Graaf, C.; Stocks, M.; Kellam, B.; Briddon, S.; et al. Modulators of CXCR4 and CXCR7/ACKR3 Function. Mol. Pharmacol. 2019, 96, 737-752. [CrossRef]

208. Nagasawa, T.; Kikutani, H.; Kishimoto, T. Molecular cloning and structure of a pre-B-cell growth-stimulating factor. Proc. Natl. Acad. Sci. USA 1994, 91, 2305-2309. [CrossRef]

209. Shirozu, M.; Nakano, T.; Inazawa, J.; Tashiro, K.; Tada, H.; Shinohara, T.; Honjo, T. Structure and chromosomal localization of the human stromal cell-derived factor 1 (SDF1) gene. Genomics 1995, 28, 495-500. [CrossRef]

210. Vasyutina, E.; Stebler, J.; Brand-Saberi, B.; Schulz, S.; Raz, E.; Birchmeier, C. CXCR4 and Gab1 cooperate to control the development of migrating muscle progenitor cells. Genes Dev. 2005, 19, 2187-2198. [CrossRef]

211. Brzoska, E.; Kowalewska, M.; Markowska-Zagrajek, A.; Kowalski, K.; Archacka, K.; Zimowska, M.; Grabowska, I.; Czerwinska, A.M.; Czarnecka-Gora, M.; Streminska, W.; et al. Sdf-1 (CXCL12) improves skeletal muscle regeneration via the mobilisation of Cxcr4 and CD34 expressing cells. Biol. Cell 2012, 104, 722-737. [CrossRef]

212. Bobadilla, M.; Sainz, N.; Abizanda, G.; Orbe, J.; Rodriguez, J.A.; Paramo, J.A.; Prosper, F.; Perez-Ruiz, A. The CXCR4/SDF1 axis improves muscle regeneration through MMP-10 activity. Stem Cells Dev. 2014, 23, 1417-1427. [CrossRef]

213. Parachikova, A.; Cotman, C.W. Reduced CXCL12/CXCR4 results in impaired learning and is downregulated in a mouse model of Alzheimer disease. Neurobiol. Dis. 2007, 28, 143-153. [CrossRef] [PubMed]

214. Yoon, J.E.; Kim, Y.; Kwon, S.; Kim, M.; Kim, Y.H.; Kim, J.H.; Park, T.J.; Kang, H.Y. Senescent fibroblasts drive ageing pigmentation: A potential therapeutic target for senile lentigo. Theranostics 2018, 8, 4620-4632. [CrossRef] [PubMed]

215. Nishiguchi, M.A.; Spencer, C.A.; Leung, D.H.; Leung, T.H. Aging suppresses skin-derived circulating SDF1 to promote full-thickness tissue regeneration. Cell Rep. 2018, 24, 3383-3392.e5. [CrossRef] [PubMed] 
216. Periyasamy-Thandavan, S.; Burke, J.; Mendhe, B.; Kondrikova, G.; Kolhe, R.; Hunter, M.; Isales, C.M.; Hamrick, M.W.; Hill, W.D.; Fulzele, S. MicroRNA-141-3p negatively modulates SDF-1 expression in age-dependent pathophysiology of human and murine bone marrow stromal cells. J. Gerontol. A Biol. Sci. Med. Sci. 2019, 74, 1368-1374. [CrossRef]

217. Wang, J.S.; Lee, M.Y.; Lien, H.Y.; Weng, T.P. Hypoxic exercise training improves cardiac/muscular hemodynamics and is associated with modulated circulating progenitor cells in sedentary men. Int. J. Cardiol. 2014, 170, 315-323. [CrossRef]

218. Emmons, R.; Niemiro, G.M.; Owolabi, O.; De Lisio, M. Acute exercise mobilizes hematopoietic stem and progenitor cells and alters the mesenchymal stromal cell secretome. J. Appl. Physiol. 2016, 120, 624-632. [CrossRef]

219. Puchert, M.; Adams, V.; Linke, A.; Engele, J. Evidence for the involvement of the CXCL12 system in the adaptation of skeletal muscles to physical exercise. Cell Signal. 2016, 28, 1205-1215. [CrossRef]

220. Yamada, M.; Hokazono, C.; Tokizawa, K.; Marui, S.; Iwata, M.; Lira, V.A.; Suzuki, K.; Miura, S.; Nagashima, K.; Okutsu, M. Muscle-derived SDF-1alpha/CXCL12 modulates endothelial cell proliferation but not exercise training-induced angiogenesis. Am. J. Physiol. Regul. Integr. Comp. Physiol. 2019, 317, R770-R779. [CrossRef]

221. Buckbinder, L.; Talbott, R.; Seizinger, B.R.; Kley, N. Gene regulation by temperature-sensitive p53 mutants: Identification of p53 response genes. Proc. Natl. Acad. Sci. USA 1994, 91, 10640-10644. [CrossRef]

222. Velasco-Miguel, S.; Buckbinder, L.; Jean, P.; Gelbert, L.; Talbott, R.; Laidlaw, J.; Seizinger, B.; Kley, N. PA26, a novel target of the p53 tumor suppressor and member of the GADD family of DNA damage and growth arrest inducible genes. Oncogene 1999, 18, 127-137. [CrossRef]

223. Parmigiani, A.; Budanov, A.V. Sensing the environment through sestrins: Implications for cellular metabolism. In International Review of Cell and Molecular Biology; Academic Press: Cambridge, MA, USA, 2016; Volume 327, pp. 1-42. [CrossRef]

224. Lee, J.H.; Budanov, A.V.; Karin, M. Sestrins orchestrate cellular metabolism to attenuate aging. Cell Metab. 2013, 18, 792-801. [CrossRef] [PubMed]

225. Lee, J.H.; Bodmer, R.; Bier, E.; Karin, M. Sestrins at the crossroad between stress and aging. Aging 2010, 2, 369-374. [CrossRef] [PubMed]

226. Lenhare, L.; Crisol, B.M.; Silva, V.R.R.; Katashima, C.K.; Cordeiro, A.V.; Pereira, K.D.; Luchessi, A.D.; da Silva, A.S.R.; Cintra, D.E.; Moura, L.P.; et al. Physical exercise increases Sestrin 2 protein levels and induces autophagy in the skeletal muscle of old mice. Exp. Gerontol. 2017, 97, 17-21. [CrossRef] [PubMed]

227. Quan, N.; Sun, W.; Wang, L.; Chen, X.; Bogan, J.S.; Zhou, X.; Cates, C.; Liu, Q.; Zheng, Y.; Li, J. Sestrin2 prevents age-related intolerance to ischemia and reperfusion injury by modulating substrate metabolism. FASEB J. 2017, 31, 4153-4167. [CrossRef] [PubMed]

228. Zeng, N.; D'Souza, R.F.; Mitchell, C.J.; Cameron-Smith, D. Sestrins are differentially expressed with age in the skeletal muscle of men: A cross-sectional analysis. Exp. Gerontol. 2018, 110, 23-34. [CrossRef] [PubMed]

229. Rai, N.; Venugopalan, G.; Pradhan, R.; Ambastha, A.; Upadhyay, A.D.; Dwivedi, S.; Dey, A.B.; Dey, S. Exploration of novel anti-oxidant protein sestrin in frailty syndrome in elderly. Aging Dis. 2018, 9, 220-227. [CrossRef] [PubMed]

230. Budanov, A.V. Stress-responsive sestrins link p53 with redox regulation and mammalian target of rapamycin signaling. Antioxid. Redox Signal. 2011, 15, 1679-1690. [CrossRef]

231. Crisol, B.M.; Lenhare, L.; Gaspar, R.S.; Gaspar, R.C.; Munoz, V.R.; da Silva, A.S.R.; Cintra, D.E.; de Moura, L.P.; Pauli, J.R.; Ropelle, E.R. The role of physical exercise on Sestrin1 and 2 accumulations in the skeletal muscle of mice. Life Sci. 2018, 194, 98-103. [CrossRef]

232. Zeng, N.; D'Souza, R.F.; Figueiredo, V.C.; Markworth, J.F.; Roberts, L.A.; Peake, J.M.; Mitchell, C.J.; Cameron-Smith, D. Acute resistance exercise induces Sestrin2 phosphorylation and p62 dephosphorylation in human skeletal muscle. Physiol. Rep. 2017, 5, e13526. [CrossRef]

233. Liu, X.; Niu, Y.; Yuan, H.; Huang, J.; Fu, L. AMPK binds to Sestrins and mediates the effect of exercise to increase insulin-sensitivity through autophagy. Metabolism 2015, 64, 658-665. [CrossRef]

234. Cordani, M.; Sanchez-Alvarez, M.; Strippoli, R.; Bazhin, A.V.; Donadelli, M. Sestrins at the interface of ROS control and autophagy regulation in health and disease. Oxid. Med. Cell. Longev. 2019, 2019, 1283075. [CrossRef] [PubMed] 
235. Kim, M.; Sujkowski, A.; Namkoong, S.; Gu, B.; Cobb, T.; Kim, B.; Kowalsky, A.H.; Cho, C.S.; Semple, I.; Ro, S.H.; et al. Sestrins are evolutionarily conserved mediators of exercise benefits. Nat. Commun. 2020, 11, 190. [CrossRef] [PubMed]

236. Villarreal, X.C.; Mann, K.G.; Long, G.L. Structure of human osteonectin based upon analysis of cDNA and genomic sequences. Biochemistry 1989, 28, 6483-6491. [CrossRef] [PubMed]

237. Bassuk, J.A.; Baneyx, F.; Vernon, R.B.; Funk, S.E.; Sage, E.H. Expression of biologically active human SPARC in Escherichia coli. Arch. Biochem. Biophys. 1996, 325, 8-19. [CrossRef]

238. Mok, S.C.; Chan, W.Y.; Wong, K.K.; Muto, M.G.; Berkowitz, R.S. SPARC, an extracellular matrix protein with tumor-suppressing activity in human ovarian epithelial cells. Oncogene 1996, 12, 1895-1901.

239. Brekken, R.A.; Sage, E.H. SPARC, a matricellular protein: At the crossroads of cell-matrix communication. Matrix Biol. 2001, 19, 816-827. [CrossRef]

240. Kos, K.; Wilding, J.P. SPARC: A key player in the pathologies associated with obesity and diabetes. Nat. Rev. Endocrinol. 2010, 6, 225-235. [CrossRef]

241. Aoi, W.; Naito, Y.; Takagi, T.; Tanimura, Y.; Takanami, Y.; Kawai, Y.; Sakuma, K.; Hang, L.P.; Mizushima, K.; Hirai, Y.; et al. A novel myokine, secreted protein acidic and rich in cysteine (SPARC), suppresses colon tumorigenesis via regular exercise. Gut 2013, 62, 882-889. [CrossRef]

242. Nakamura, K.; Nakano, S.; Miyoshi, T.; Yamanouchi, K.; Matsuwaki, T.; Nishihara, M. Age-related resistance of skeletal muscle-derived progenitor cells to SPARC may explain a shift from myogenesis to adipogenesis. Aging 2012, 4, 40-48. [CrossRef]

243. Nakamura, K.; Nakano, S.; Miyoshi, T.; Yamanouchi, K.; Nishihara, M. Loss of SPARC in mouse skeletal muscle causes myofiber atrophy. Muscle Nerve 2013, 48, 791-799. [CrossRef]

244. Nakamura, K.; Yamanouchi, K.; Nishihara, M. Secreted protein acidic and rich in cysteine internalization and its age-related alterations in skeletal muscle progenitor cells. Aging Cell 2014, 13, 175-184. [CrossRef] [PubMed]

245. Jorgensen, L.H.; Jepsen, P.L.; Boysen, A.; Dalgaard, L.B.; Hvid, L.G.; Ortenblad, N.; Ravn, D.; Sellathurai, J.; Moller-Jensen, J.; Lochmuller, H.; et al. SPARC interacts with actin in skeletal muscle in vitro and in vivo. Am. J. Pathol. 2017, 187, 457-474. [CrossRef] [PubMed]

246. Catoire, M.; Mensink, M.; Kalkhoven, E.; Schrauwen, P.; Kersten, S. Identification of human exercise-induced myokines using secretome analysis. Physiol. Genom. 2014, 46, 256-267. [CrossRef]

247. Tai, I.T.; Tang, M.J. SPARC in cancer biology: Its role in cancer progression and potential for therapy. Drug Resist. Updat. 2008, 11, 231-246. [CrossRef] [PubMed]

248. Tai, I.T.; Dai, M.; Owen, D.A.; Chen, L.B. Genome-wide expression analysis of therapy-resistant tumors reveals SPARC as a novel target for cancer therapy. J. Clin. Investig. 2005, 115, 1492-1502. [CrossRef]

249. Songsorn, P.; Ruffino, J.; Vollaard, N.B. No effect of acute and chronic supramaximal exercise on circulating levels of the myokine SPARC. Eur. J. Sport Sci. 2017, 17, 447-452. [CrossRef]

250. Said, N.; Frierson, H.F., Jr.; Chernauskas, D.; Conaway, M.; Motamed, K.; Theodorescu, D. The role of SPARC in the TRAMP model of prostate carcinogenesis and progression. Oncogene 2009, 28, 3487-3498. [CrossRef] [PubMed]

251. Senger, D.R.; Galli, S.J.; Dvorak, A.M.; Perruzzi, C.A.; Harvey, V.S.; Dvorak, H.F. Tumor cells secrete a vascular permeability factor that promotes accumulation of ascites fluid. Science 1983, 219, 983-985. [CrossRef] [PubMed]

252. Leung, D.W.; Cachianes, G.; Kuang, W.J.; Goeddel, D.V.; Ferrara, N. Vascular endothelial growth factor is a secreted angiogenic mitogen. Science 1989, 246, 1306-1309. [CrossRef]

253. Achen, M.G.; Stacker, S.A. The vascular endothelial growth factor family; proteins which guide the development of the vasculature. Int. J. Exp. Pathol. 1998, 79, 255-265. [CrossRef]

254. Vital, T.M.; Stein, A.M.; de Melo Coelho, F.G.; Arantes, F.J.; Teodorov, E.; Santos-Galduroz, R.F. Physical exercise and vascular endothelial growth factor (VEGF) in elderly: A systematic review. Arch. Gerontol. Geriatr. 2014, 59, 234-239. [CrossRef]

255. Ahluwalia, A.; Jones, M.K.; Szabo, S.; Tarnawski, A.S. Aging impairs transcriptional regulation of vascular endothelial growth factor in human microvascular endothelial cells: Implications for angiogenesis and cell survival. J. Physiol. Pharmacol. 2014, 65, 209-215. [PubMed] 
256. Ryan, N.A.; Zwetsloot, K.A.; Westerkamp, L.M.; Hickner, R.C.; Pofahl, W.E.; Gavin, T.P. Lower skeletal muscle capillarization and VEGF expression in aged vs. young men. J. Appl. Physiol. 2006, 100, 178-185. [CrossRef] [PubMed]

257. Olfert, I.M.; Howlett, R.A.; Tang, K.; Dalton, N.D.; Gu, Y.; Peterson, K.L.; Wagner, P.D.; Breen, E.C. Muscle-specific VEGF deficiency greatly reduces exercise endurance in mice. J. Physiol. 2009, 587, 1755-1767. [CrossRef] [PubMed]

258. Gustafsson, T.; Bodin, K.; Sylven, C.; Gordon, A.; Tyni-Lenne, R.; Jansson, E. Increased expression of VEGF following exercise training in patients with heart failure. Eur. J. Clin. Investig. 2001, 31, 362-366. [CrossRef] [PubMed]

259. Ohno, H.; Shirato, K.; Sakurai, T.; Ogasawara, J.; Sumitani, Y.; Sato, S.; Imaizumi, K.; Ishida, H.; Kizaki, T. Effect of exercise on HIF-1 and VEGF signaling. J. Phys. Fit. Sports Med. 2012, 1, 5-16. [CrossRef]

260. Rich, B.; Scadeng, M.; Yamaguchi, M.; Wagner, P.D.; Breen, E.C. Skeletal myofiber vascular endothelial growth factor is required for the exercise training-induced increase in dentate gyrus neuronal precursor cells. J. Physiol. 2017, 595, 5931-5943. [CrossRef]

261. Samitz, G.; Egger, M.; Zwahlen, M. Domains of physical activity and all-cause mortality: Systematic review and dose-response meta-analysis of cohort studies. Int. J. Epidemiol. 2011, 40, 1382-1400. [CrossRef]

262. Katzmarzyk, P.T.; Janssen, I.; Ardern, C.I. Physical inactivity, excess adiposity and premature mortality. Obes. Rev. 2003, 4, 257-290. [CrossRef]

263. Taylor, A.H.; Cable, N.T.; Faulkner, G.; Hillsdon, M.; Narici, M.; Van Der Bij, A.K. Physical activity and older adults: A review of health benefits and the effectiveness of interventions. J. Sports Sci. 2004, 22, 703-725. [CrossRef]

264. Liposcki, D.B.; da Silva Nagata, I.F.; Silvano, G.A.; Zanella, K.; Schneider, R.H. Influence of a Pilates exercise program on the quality of life of sedentary elderly people: A randomized clinical trial. J. Bodyw. Mov. Ther. 2019, 23, 390-393. [CrossRef] [PubMed]

265. Habchi, H.; Lorenzo-Villalba, N.; Andres, E.; Zulfiqar, A.A. Physical activity among seniors: What benefits on geriatric criteria? Rev. Med. Liege 2020, 75, 89-93. [PubMed]

266. Nuzum, H.; Stickel, A.; Corona, M.; Zeller, M.; Melrose, R.J.; Wilkins, S.S. Potential benefits of physical activity in MCI and dementia. Behav. Neurol. 2020, 2020, 7807856. [CrossRef] [PubMed]

267. Chen, W.W.; Zhang, X.; Huang, W.J. Role of physical exercise in Alzheimer's disease. Biomed. Rep. 2016, 4, 403-407. [CrossRef] [PubMed]

268. Blondell, S.J.; Hammersley-Mather, R.; Veerman, J.L. Does physical activity prevent cognitive decline and dementia? A systematic review and meta-analysis of longitudinal studies. BMC Public Health 2014, 14, 510. [CrossRef] [PubMed]

269. Moore, S.C.; Lee, I.M.; Weiderpass, E.; Campbell, P.T.; Sampson, J.N.; Kitahara, C.M.; Keadle, S.K.; Arem, H.; Berrington de Gonzalez, A.; Hartge, P.; et al. Association of leisure-time physical activity with risk of 26 types of cancer in 1.44 million adults. JAMA Intern. Med. 2016, 176, 816-825. [CrossRef]

270. Heitmann, B.L.; Frederiksen, P. Thigh circumference and risk of heart disease and premature death: Prospective cohort study. BMJ 2009, 339, b3292. [CrossRef]

271. McCurdy, A.P.; Boule, N.G.; Sivak, A.; Davenport, M.H. Effects of exercise on mild-to-moderate depressive symptoms in the postpartum period: A meta-analysis. Obstet. Gynecol. 2017, 129, 1087-1097. [CrossRef]

272. Aarsland, D.; Sardahaee, F.S.; Anderssen, S.; Ballard, C.; Alzheimer's Society Systematic Review Group. Is physical activity a potential preventive factor for vascular dementia? A systematic review. Aging Ment. Health 2010, 14, 386-395. [CrossRef]

273. Etgen, T.; Bickel, H.; Forstl, H. Metabolic and endocrine factors in mild cognitive impairment. Ageing Res. Rev. 2010, 9, 280-288. [CrossRef]

274. Lautenschlager, N.T.; Cox, K.L.; Flicker, L.; Foster, J.K.; van Bockxmeer, F.M.; Xiao, J.; Greenop, K.R.; Almeida, O.P. Effect of physical activity on cognitive function in older adults at risk for Alzheimer disease: A randomized trial. JAMA 2008, 300, 1027-1037. [CrossRef] [PubMed]

275. Feskanich, D.; Willett, W.; Colditz, G. Walking and leisure-time activity and risk of hip fracture in postmenopausal women. JAMA 2002, 288, 2300-2306. [CrossRef] [PubMed]

276. Boone-Heinonen, J.; Evenson, K.R.; Taber, D.R.; Gordon-Larsen, P. Walking for prevention of cardiovascular disease in men and women: A systematic review of observational studies. Obes. Rev. 2009, 10, $204-217$. [CrossRef] [PubMed] 
277. Ma, D.; Wu, L.; He, Z. Effects of walking on the preservation of bone mineral density in perimenopausal and postmenopausal women: A systematic review and meta-analysis. Menopause 2013, 20, 1216-1226. [CrossRef] [PubMed]

278. Janssen, I.; Shepard, D.S.; Katzmarzyk, P.T.; Roubenoff, R. The healthcare costs of sarcopenia in the United States. J. Am. Geriatr. Soc. 2004, 52, 80-85. [CrossRef]

279. Ray, N.F.; Chan, J.K.; Thamer, M.; Melton, L.J., 3rd. Medical expenditures for the treatment of osteoporotic fractures in the United States in 1995: Report from the National Osteoporosis Foundation. J. Bone Miner. Res. 1997, 12, 24-35. [CrossRef]

(C) 2020 by the authors. Licensee MDPI, Basel, Switzerland. This article is an open access article distributed under the terms and conditions of the Creative Commons Attribution (CC BY) license (http://creativecommons.org/licenses/by/4.0/). 